\title{
Central pathways integrating metabolism and reproduction in teleosts
}

\author{
Md. Shahjahan ${ }^{\dagger}$, Takashi Kitahashi $^{\dagger}$ and Ishwar S. Parhar* \\ Brain Research Institute, School of Medicine and Health Sciences, Monash University Malaysia, Petaling Jaya, Malaysia
}

Edited by:

Rosaria Meccariello, University of

Naples Parthenope, Italy

\section{Reviewed by:}

Teresa Chioccarelli, Second University of Naples, Italy

Erika Cottone, University of Turin, Italy

*Correspondence:

Ishwar S. Parhar, Brain Research Institute, School of Medicine and Health Sciences, Monash University

Malaysia, Petaling Jaya 46150,

Malaysia

e-mail: ishwar@monash.edu

${ }^{+}$Md. Shahjahan and Takashi Kitahashi have contributed equally to this work.
Energy balance plays an important role in the control of reproduction. However, the cellular and molecular mechanisms connecting the two systems are not well understood especially in teleosts. The hypothalamus plays a crucial role in the regulation of both energy balance and reproduction, and contains a number of neuropeptides, including gonadotropinreleasing hormone $(\mathrm{GnRH})$, orexin, neuropeptide-Y, ghrelin, pituitary adenylate cyclaseactivating polypeptide, $\alpha$-melanocyte stimulating hormone, melanin-concentrating hormone, cholecystokinin, 26RFamide, nesfatin, kisspeptin, and gonadotropin-inhibitory hormone. These neuropeptides are involved in the control of energy balance and reproduction either directly or indirectly. On the other hand, synthesis and release of these hypothalamic neuropeptides are regulated by metabolic signals from the gut and the adipose tissue. Furthermore, neurons producing these neuropeptides interact with each other, providing neuronal basis of the link between energy balance and reproduction. This review summarizes the advances made in our understanding of the physiological roles of the hypothalamic neuropeptides in energy balance and reproduction in teleosts, and discusses how they interact with $\mathrm{GnRH}$, kisspeptin, and pituitary gonadotropins to control reproduction in teleosts.

Keywords: neuropeptide, metabolism, energy balance, fish, reproduction

\section{INTRODUCTION}

A close connection between energy balance and reproduction has been well documented in mammals (1). Energy balance is maintained by a process that controls food consumption, energy expenditure, and energy storage. A number of hypothalamic neuropeptides including orexin, ghrelin, neuropeptide-Y (NPY), melaninconcentrating hormone $(\mathrm{MCH})$, pituitary adenylate cyclaseactivating polypeptide (PACAP), proopiomelanocortin (POMC)derived peptides, cholecystokinin (CCK), chicken gonadotropinreleasing hormone-II (cGnRH-II), 26RFamide (26RFa), galanin (GAL), and cocaine- and amphetamine-regulated transcript (CART) have been implicated in the regulation of feeding behavior and energy balance. On the other hand, peripheral hormones such as leptin and ghrelin provide information about the availability of stored metabolic foods.

Initiation of reproduction is affected by the amount of body energy reserves and is responsive to diverse metabolic factors. The neuroendocrine mechanisms responsible for the association between energy balance and fertility are represented by metabolic hormones and neuropeptides that affect the hypothalamic center controlling the expression and release of gonadotropin-releasing hormone $(\mathrm{GnRH})(2,3)$. Therefore, adequate body energy stores are crucial for full activation of the hypothalamus-pituitarygonadal (HPG) axis at puberty and its proper functioning in adulthood (4). Generally high amount of food supply favor reproduction, while low food supply inhibits the reproductive system (1). During energetic challenges, the physiological mechanisms that partition energy into various activities tend to favor the processes for the survival of the individual over the processes for growth, longevity, and reproduction (5). Therefore, the reproductive system is suppressed by energetic challenges. At the same time it is also true that when the reproductive system is highly activated, animal primates reproduction rather than feeding. Many factors such as starvation, eating disorders, excessive exercise, cold exposure, and lactation act on both food intake and reproduction by increasing hunger and/or food ingestion and by suppressing reproductive processes $(5,6)$.

Most feeding-related neuropeptides in mammals have also been identified in fish species (7), suggesting that the regulatory system of feeding has been well conserved from fish to mammals. On the other hand, as the links between energy balance and reproduction have been demonstrated in several vertebrates (8), this might also exist in teleosts. Indeed, seasonal changes in feeding often coincide with spawning migration and reproduction in fish, suggesting association between nutrition and reproduction (9).

This review focuses on the role of the neuropeptides that regulate feeding and energy balance on reproduction in teleosts, and discusses if the metabolic control of reproduction is conserved from fish to mammals.

\section{REGULATION OF REPRODUCTION IN TELEOSTS}

In teleosts, as in other vertebrates, reproduction is coordinated by the HPG axis. The hypothalamus produces $\mathrm{GnRH}$, which regulates the synthesis and release of gonadotropins (GTHs), follicle-stimulating hormone (FSH), and luteinizing hormone (LH), from the pituitary. The GTHs act on the gonads to stimulate gonadal development through the secretion of sex steroid hormones. These steroids, in turn, feedback to the brain and the 
pituitary to complete the HPG axis and to regulate the reproductive cycle $(10,11)$. Thus, hypothalamic GnRH is considered as the key player in the regulation of reproduction in teleosts. Furthermore, recent findings of kisspeptin and gonadotropin-inhibitory hormone $(\mathrm{GnIH})$ added new players in the reproductive system, which stimulate and inhibit mostly GnRH neurons, respectively.

\section{GONADOTROPIN-RELEASING HORMONE (GnRH)}

In the early 1970s, two research groups simultaneously reported the isolation of a LH-releasing factor from the hypothalamus of pigs and sheep $(12,13)$, and named it LH-releasing hormone (LHRH). Later, this decapeptide was also found to stimulate FSH release, and accordingly re-named GnRH. The GnRH isolated from mammals is also functional in fish, and stimulates the release of GTH in the carp (14). The first fish GnRH was identified in salmon, and named as salmon GnRH (sGnRH) (15). To date, 15 different forms of GnRH have been identified in vertebrates (13, 15-25), among them 10 original forms in fish species: salmon, sea bream, whitefish, medaka, catfish, herring, dogfish, and lamprey (lamprey I, II, and III). Most vertebrates possess two, and some teleosts have three, forms of $\mathrm{GnRH}$ in the brain $(23,25-$ 31). Based on phylogenetic analysis, recent classification defines the species-specific (hypophysiotropic) form as GnRH1, while the most evolutionarily conserved chicken GnRH-II as GnRH2 (32). The third form is GnRH3 (33), which is present only in the brain of certain teleost species $(31,34)$.

Distribution of three different forms of $\mathrm{GnRH}$ in the brain was first reported in a perciform fish, the sea bream (35). GnRH1 neurons are generally present in the region from the ventral forebrainpreoptic area (POA) to basal hypothalamus, whereas GnRH2 neurons are restricted to the dorsal mesencephalon. GnRH3 neurons are located in the caudal-most olfactory bulb as a ganglion and along the terminal nerve in most fish species that possess three GnRH forms $(31,36)$. On the other hand, in the sea bream and the European sea bass, the distribution of GnRH1 and GnRH3 cells overlap in the olfactory bulbs, ventral telencephalon, and POA (37-40). Similar results were reported in several other fish species (41-45). In the sea bass brain, GnRH1 neuronal fibers are observed in the ventral surface of the forebrain, associated with the ventral telencephalon, POA, and the hypothalamus, whereas GnRH2 and GnRH3 neuronal fibers show profuse distributions throughout the brain (40).

The function of $\mathrm{GnRH}$ in the central regulation of $\mathrm{LH}$ release has been recognized in all orders of teleosts. Although the assay for FSH peptide is lacking for most fish species, studies in the rainbow trout (46-48) and the Coho salmon (49) show that GnRH also stimulates FSH release in salmonids. However, the different patterns of fiber projections of each GnRH form suggest different physiological function of each GnRH form in the brain (31). GnRH1 neurons are generally present in the ventral forebrainPOA-hypothalamus and send neuronal fibers directly into the pituitary, which represents its primary role in the stimulation of GTH secretion. The physiological significance of GnRH1 as a regulator of GTH secretion and gametogenesis has been established in several teleosts $(28,50-54)$.

GnRH2 neurons are exclusively present in the midbrain. The absence or low levels of GnRH2 peptide in the pituitary has been demonstrated in several perciformes $(50,51,55-57)$ and pleuronectiformes species $(28,58)$, suggesting that GnRH2 is not directly involved in GTH secretion. Rather, its wide fiber projection throughout the brain suggests that $\mathrm{GnRH} 2$ has neuromodulatory functions (30). However, in some fish species including the goldfish, GnRH2 seems to act as a hypophysiotropic GnRH together with GnRH3 (59).

GnRH3 has been shown to control reproductive behaviors in several fish species. GnRH3 stimulates nest-building behavior in the male dwarf gourami (60), homing migration in the sockeye salmon (61), and aggressive and nest-building behaviors in the male Nile tilapia (62), which suggests probable neuromodulatory roles of GnRH3. The neuromodulatory role of $\mathrm{GnRH} 3$ was confirmed by electrophysiological studies in the retina of goldfish $(63,64)$ and olfactory receptor cells of the mudpuppy $(65)$. The neuromodulatory function of $\mathrm{GnRH} 3$ has also been demonstrated in the rainbow trout $(66,67)$ and the dwarf gourami [reviewed by Oka (68)]. Fish species such as some salmonids and the zebrafish possess only two forms of GnRH (GnRH2 and GnRH3). In these species, GnRH3 expressed in the basal forebrain acts as a hypophysiotropic $\mathrm{GnRH}(45,69-71)$.

\section{KISSPEPTIN}

Kisspeptin is a neuropeptide that plays an important role in reproduction through the stimulation of $\mathrm{GnRH}$ neurons by activating GPR54 in mammals $(72,73)$. In teleosts, two kisspeptin genes, namely kiss1 and kiss2, have been identified in several fish species (74-77), whereas placental mammals possess only the kiss1 gene. Similarly, two kisspeptin receptor genes, named kiss1r and kiss $2 r$, were also identified in several fish species $(76,78)$, suggesting two Kiss/Kissr systems in teleosts. However, this situation is not common among all fish species. Only one kisspeptin gene, kiss2, and one receptor, kiss $2 r$, are present in some fish species including the Senegalese sole (79), orange-spotted grouper (80), grass puffer (81), and the Atlantic halibut (82), indicating that the kiss1 and kiss1r genes have been lost during evolution in these species (82). Both kiss 1 and kiss 2 mRNAs are expressed in the brain and the gonads in several fish species $(74,76-78,83)$. On the other hand, kisspeptin and kisspeptin receptor are also expressed in the fish pituitary, suggesting local actions of kisspeptin in the pituitary $(76,78,81)$. In the medaka brain, two populations of kiss1 neurons are found in the hypothalamus, one in the nucleus ventral tuberis $(\mathrm{nVT})$ and the nucleus posterioris periventricularis $(\mathrm{NPPv})(74,84)$, while neurons in the dorsal zone of the periventricular hypothalamus ( $\mathrm{Hd}$ ) express kiss2. In the zebrafish all hypothalamic populations express kiss2 mRNA (74). A recent study showed that zebrafish Kiss2 neuronal fibers are found widely in the subpallium, POA, ventral and caudal hypothalamus, and the mesencephalon (85). The fact that all three GnRH neuron types express kisspeptin receptors in the Nile tilapia (86) suggests that the role of Kiss 2 neurons in the regulation of the HPG axis is via the activation of the GnRH systems. The kiss1 neurons are exclusively localized in the habenula in the zebrafish (74), and send fibers only to the ventral part of the interpeduncular nucleus (85, 87). The habenula Kiss1 system is thus implicated in the modulation of serotonergic system rather than the HPG axis in the zebrafish (87). 
The role of kisspeptin in the onset of puberty and sexual maturation is conserved among vertebrates including fish. In the zebrafish, both kiss 1 and kiss 2 mRNA levels are increased significantly at the start of the pubertal phase together with $\mathrm{GnRH} 2$ and GnRH3 mRNAs (74). Significant positive correlation is observed between the levels of kiss 2 mRNA and those of gnrh 1 mRNA during the spawning period in the grass puffer (81). Kiss2 but not Kiss 1 stimulates GTH synthesis and release in the sea bass and the zebrafish $(74,75)$. Administration of Kiss2-10 peptide increases GnRH1 mRNA levels in the sexually mature female orange-spotted grouper (80), indicating that Kiss 2 most probably plays an important role in the regulation of reproductive functions through the stimulation of GnRH1 secretion.

The information of the interaction between kisspeptin neuronal fibers and GnRH cell bodies had been limited in teleosts due to the lack of specific antibody to kisspeptins. A recent study using an antibody to prepro-Kiss2 proved that Kiss2 neuronal fibers make close contacts with POA GnRH (GnRH3) neurons in the zebrafish (85), suggesting that Kiss2 directly act on GnRH neurons. Moreover, kisspeptin receptor expression in the three GnRH neuronal populations (86) in tilapia suggests that kisspeptin directly stimulates not only GnRH1 neurons to induce LH secretion, but also GnRH2 and GnRH3 neurons to activate other aspects of the reproduction such as sexual behavior.

\section{GONADOTROPIN-INHIBITORY HORMONE (GnIH)}

GnIH or RFamide-related peptide (RFRP), which has a characteristic C-terminal LPXRFa motif ( $\mathrm{X}=\mathrm{L}$ or $\mathrm{Q})$, is a hypothalamic neuropeptide that was originally identified from the quail as a neuropeptide that inhibits gonadotropin release from the pituitary (88). Extensive studies revealed that GnIH functions at the level of GnRH neurons and at the level of pituitary gonadotropes to suppress reproduction in avian and mammalian species [see reviews in Ref. $(89,90)]$. GnIH in the teleost species has been named LPXRFamide peptide based on the amino acid sequence of the C-terminal motif. All precursors of teleost $\mathrm{GnIH}$ identified so far encode three GnIH orthologs (LPXRFa-1, -2, and -3), while only goldfish LPXRFa-3 has been purified as a mature peptide.

As in birds and in mammals, teleost GnIH neurons are located in the hypothalamus, in particular in the NPPv, and send neuronal fibers throughout the brain and to the pituitary $(91,92)$. The physiological function of teleost $\mathrm{GnIH}$ in the control of reproduction is complicated. In vivo studies using the goldfish show that $\mathrm{GnIH}$ decreases plasma LH levels as in avian and mammalian species $(93,94)$. On the other hand, GnIH significantly increases pituitary levels of mRNAs for $\mathrm{LH} \beta$ and FSH $\beta$ in a reproductive state-dependent manner in vivo, whereas general suppression of $\mathrm{LH} \beta$ and FSH $\beta$ mRNA levels is observed in vitro in a study (93). This differential in vivo effect of GnIH in different seasons can be explained by the differential action of GnIH on the gonads (95). GnIH does not affect plasma estradiol levels in the female goldfish, but increases plasma testosterone levels in the male goldfish (96). $\mathrm{GnIH}$ injections into the female goldfish suppress pituitary $\mathrm{LH} \beta$ and FSH $\beta$ and hypothalamic GnRH mRNA levels (95). In addition, GnIH suppresses GnRH-induced increase in LH $\beta$ mRNA levels in vitro (95). Therefore, in the goldfish, the inhibition of the HPG axis at the level of hypothalamic GnRH neurons and pituitary gonadotropes appears as an evolutionarily conserved function of GnIH. On the contrary, goldfish GnIH peptides stimulate the synthesis and release of $\mathrm{LH}$ and FSH in cultured pituitary cells of the grass puffer and the sockeye salmon, respectively $(92,97)$. Therefore, as in mammals (98), the stimulatory or inhibitory action of $\mathrm{GnIH}$ in fish is probably species dependent or species-specific $\mathrm{GnIH}$ peptide might be necessary for an inhibitory action.

More recently, it has been shown that medaka LPXRFa2 (GnIH-2) peptide decreases the firing frequency of nonhypophsiotropic terminal nerve GnRH3 neurons in the dwarf gourami (99). Since GnRH3 controls nest-building, aggression, and homing migration (60-62), GnIH-2 might negatively regulate reproductive behaviors.

\section{METABOLIC NEUROPEPTIDES INVOLVED IN REPRODUCTION}

A number of hypothalamic neuropeptides have been identified in fish species (7), and found to be involved in the control of food intake as well as reproduction (Table 1). To understand the overall metabolic control of reproduction, the involvement of metabolic neuropeptides in the regulation of $\mathrm{GnRH}$ and GTHs must be taken into consideration. However, compared to mammals, the information related to the role of metabolic neuropeptides in the regulation of reproduction is still limited in fish.

\section{OREXIN}

Orexin has two well conserved molecular forms, a 33-amino acid peptide known as orexin A (OXA) and a 28-amino acid peptide known as orexin $\mathrm{B}(\mathrm{OXB})$ derived from the same precursor [see review in Ref. (150)]. Orexin was first identified as a ligand of an orphan receptor, and consequently found to stimulate feeding in mammals (151). The orexin's orexigenic action is also observed in teleosts, including the goldfish and the ornate wrasse $(101,152)$.

In mammals, orexin is known to stimulate the HPG axis via GnRH secretion (153-155). In the goldfish, an interaction between orexin and hypophysiotropic GnRH (GnRH2) has also been proposed. Intracerebroventricular administrations of OXA inhibit spawning behavior and lower GnRH2 mRNA levels, while treatment with GnRH decreases OXA mRNA levels (102). These results suggest that, unlike in mammals, orexins might act as inhibitory agents in the control of GnRH at least in some fish species. In addition, OXA is detected in the pituitary of the medaka (156) and the Japanese sea perch (157), whilst OXB is detected in the pituitary of the Nile tilapia (158), suggesting orexin's local action at the level of pituitary. Thus orexin, an orexigenic neuropeptide, inhibits the HPG axis at the hypothalamus GnRH level and possibly also at the pituitary level, in fish.

\section{NEUROPEPTIDE-Y (NPY)}

NPY which is composed of 36 amino acid residues, was first identified in the porcine brain (159), and was found to function as a powerful appetite enhancer in mammals (160). In fish species, NPY also show powerful orexigenic activity in the goldfish $(103,123,161-164)$, trout (104), puffer fish $(105,165)$, and the zebrafish (106).

Centrally or peripherally injected NPY increases plasma LH levels in the goldfish, common carp, rainbow trout, and in the sea bass $(107,109,111)$, indicating that NPY stimulates teleost reproduction as was shown in mammals (166). 
Table 1 | Neuropeptides and their functions in representative fish species.

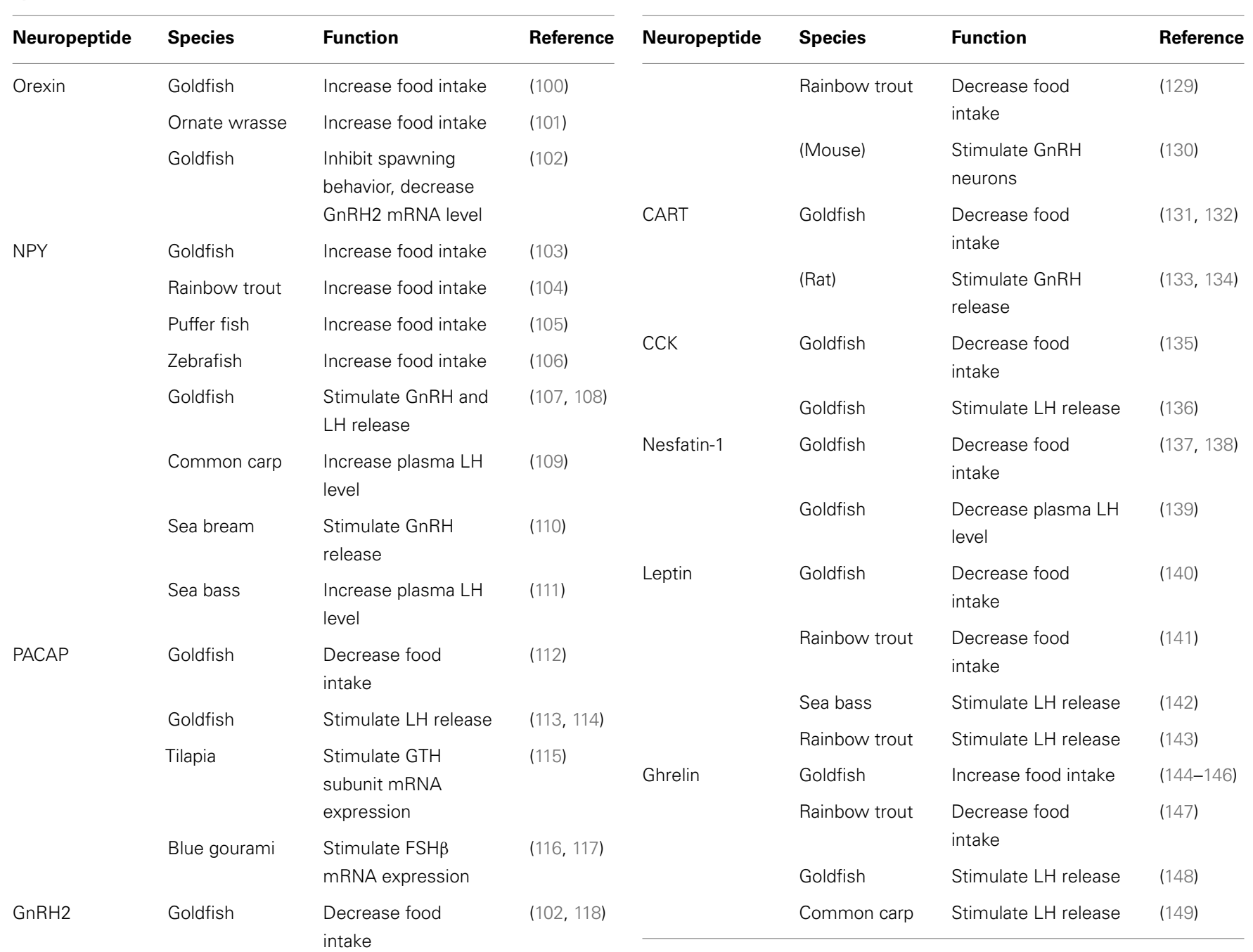

\begin{tabular}{|c|c|c|c|}
\hline & Goldfish & Stimulate LH release & (120) \\
\hline \multirow[t]{2}{*}{ 26RFa } & Mouse & Increase food intake & (121) \\
\hline & Goldfish & $\begin{array}{l}\text { Increase plasma LH } \\
\text { level }\end{array}$ & (122) \\
\hline \multirow[t]{3}{*}{ Galanin } & Goldfish & Increase food intake & (123) \\
\hline & Tench & Increase food intake & (124) \\
\hline & (Rat) & $\begin{array}{l}\text { Stimulate } \mathrm{GnRH} \\
\text { release }\end{array}$ & (125) \\
\hline \multirow[t]{2}{*}{$\mathrm{MCH}$} & Goldfish & $\begin{array}{l}\text { Decrease food } \\
\text { intake }\end{array}$ & (126) \\
\hline & Goldfish & Stimulate LH release & (127) \\
\hline$\alpha-\mathrm{MSH}$ & Goldfish & $\begin{array}{l}\text { Decrease food } \\
\text { intake }\end{array}$ & (128) \\
\hline
\end{tabular}

In the brown trout (167) and the rainbow trout (168), NPY neuronal fibers project to the areas where hypophysiotropic $\mathrm{GnRH}$ neurons exist, particularly in the ventral telencephalon, POA, and in the basal hypothalamus. Furthermore, double immunolabeling reveals close appositions of NPY fibers with GnRH cells in the POA of the ayu (Plecoglossus altivelis) (169) and the Siberian sturgeon (170), suggesting the direct action of NPY in the regulation of GnRH neurons. Indeed, NPY stimulates GnRH release in vitro in the goldfish (108) and in the sea bream (110).

Neuropeptide-Y also regulates the HPG axis at the level of pituitary. In vitro treatment with NPY stimulates LH release from pituitary cells in the goldfish (107) and increases LH $\beta$ and GTH $\alpha$, but not FSH $\beta$ mRNA levels in the tilapia pituitary (115). In addition, NPY fibers make close appositions on LH cells in the catfish pituitary (171).

These findings provide strong support for the stimulatory role of NPY in fish reproduction at the levels of hypothalamic GnRH and pituitary LH cells. 


\section{RFamide (QRFP)}

26RFamide is a 26-amino acid peptide, and was first isolated from the frog brain (121). In teleosts, 26RFa has been identified only in the goldfish (172). The 26RFa gene is highly expressed in the hypothalamus, and relatively less in the optic tectum-thalamus and in the testis (122). 26RFa and its mammalian homolog QRFP act as an orexigenic hormone in birds, mice (121, 172-174), and probably in fish (122).

The role of $26 \mathrm{RFa}$ has been implicated in the integration of metabolism and reproduction in vertebrates, including fish [see review in Ref. (89)]. In mammals, 26RFa stimulates LH and FSH release in rats in vivo and in vitro (pituitary culture) (175). In teleost, intraperitoneal injections of 26RFa significantly increase plasma LH levels in the goldfish (122). On the other hand, in vitro treatment with $26 \mathrm{RFa}$ shows no effects on $\mathrm{LH}$ release from pituitary cells. These facts indicate that $26 \mathrm{RFa}$ might act on the stimulation of the HPG axis through GnRH1 release in fish.

\section{GALANIN (GAL)}

GAL is a 29-amino acid peptide, expressed in the central nervous system and in the intestine. GAL stimulates feeding in the goldfish (123) and the doctor fish tench (124), indicating that GAL acts as an orexigenic hormone in fish as in mammals $(176,177)$.

Involvement of GAL in the control of HPG axis is evidenced in mammals. In rodents and humans, GAL neuronal fibers make close appositions with GnRH1 neurons (178-180), and GnRH neurons express a GAL receptor Gal-R1 in the rat (181). In fact, GAL stimulates in vitro GnRH release in rats (125). These data indicate that GAL is involved in the control of reproduction at the level of GnRH neurons.

In fish, there are no studies that demonstrated the role of GAL in the control of reproduction. However, close appositions of GAL fibers with gonadotropes in the proximal pars distalis (PPD) are seen in the sea bass (182). Similarly, fiber projections of GAL neurons in the PPD are observed in the rainbow trout (183), sea bream (184), and Senegalese sole (185), while no GAL fibers are observed in the pituitary of the Siberian sturgeon (170). Therefore, GAL might modulate the HPG axis at the pituitary level at least in some fish species.

\section{GnRH2}

As mentioned before, among the different forms of $\mathrm{GnRH}$, neuronal fibers of GnRH2 (also known as chicken GnRH-II) are widely distributed in the vertebrate brain. In an insectivore, the musk shrew, GnRH2 stimulates sexual behavior and seduces food intake $(186,187)$, indicating that GnRH2 plays a role in connecting reproductive function and feeding regulation.

In fish species, the suppressive effect of $\mathrm{GnRH} 2$ on feeding has also been confirmed. Food consumption is significantly decreased by intracerebroventricular injections of GnRH2 but not GnRH3 in a dose dependent manner in the goldfish $(102,118)$ and the zebrafish (119).

GnRH2 also has effects on sexual behavior of fish. In the goldfish, GnRH2 stimulates reproductive behavior (188). Furthermore, there is a strong positive correlation between spawning behavior and GnRH2 gene expression (189), suggesting stimulatory role of $\mathrm{GnRH} 2$ in reproductive behavior. $\mathrm{GnRH} 2$ is also detected in the goldfish pituitary (190) and induces LH release in vitro (120). Positive correlation between the pituitary GnRH2 levels and gonadal development is also observed in the striped bass (51), suggesting that it also have a hypophysiotropic role in some fish species. In the grass puffer, the amount of GnRH2 mRNA is slightly higher in the post-spawning females compared to spawning female (191). Therefore, GnRH2 may have different physiological roles depending on the physiological conditions of the fish.

\section{PITUITARY ADENYLATE CYCLASE-ACTIVATING POLYPEPTIDE (PACAP)}

PACAP was first isolated from the rat hypothalamus (192). PACAP is an anorexigenic factor in various vertebrates, including rodents (193), chicks (194, 195), and fish (196). To date, the role of PACAP in feeding has been studied only in one fish species, the goldfish.

PACAP increases plasma LH levels in vivo in the goldfish (197). In vitro studies showed that the stimulatory effect of PACAP on LH release is exerted at the level of the pituitary $(113,114)$. PACAP also stimulates the levels of GTH subunit mRNAs and FSH $\beta$ mRNA in the pituitary of tilapia (115) and in the female blue gourami (116, 117), respectively. Dense projection of PACAP nerve terminals is seen in the pars distalis of the pituitary, where gonadotropes are localized, in the goldfish (198) and in the European eel (199). The expression of PACAP receptor in the pituitary is also observed in the goldfish (197). Therefore, PACAP stimulates GTH secretion in fish pituitary.

\section{MELANIN-CONCENTRATING HORMONE (MCH)}

$\mathrm{MCH}$ is a cyclic peptide, originally isolated from the pituitary of the chum salmon as a hormone involved in body color change (200). In the winter and barfin flounders, fasting stimulates hypothalamic expression of $\mathrm{MCH}(201,202)$, suggesting that $\mathrm{MCH}$ acts as an orexigenic hormone as in mammals (203,204). However, $\mathrm{MCH}$ acts as an anorexigenic hormone in the goldfish $(105,126$, 205, 206). Therefore, like ghrelin, $\mathrm{MCH}$ acts as an orexigenic and anorexigenic neuropeptide depending on the fish species, although its orexigenic action in fish has to be confirmed.

In mammals, MCH modulates $\mathrm{LH}$ secretion in an estradioldependent manner [see a review in Ref. (207)]. The close appositions between $\mathrm{MCH}$ fibers and hypothalamic GnRH neurons (208, 209) and the expression of MCH receptors in GnRH neurons (209) suggest the direct action of $\mathrm{MCH}$ on $\mathrm{GnRH}$ neurons in mammals. $\mathrm{MCH}$ also acts at the pituitary level to modulate the release of $\mathrm{LH}$ (210). In teleosts, an in vitro study showed that salmon MCH stimulates the release of $\mathrm{LH}$ in a dose response manner from dispersed pituitary cells in the goldfish, suggesting a direct action of $\mathrm{MCH}$ on LH cells (127). Whether MCH acts on GnRH neurons in fish as in mammals remains unknown.

\section{$\alpha$-MELANOCYTE STIMULATING HORMONE ( $\alpha$-MSH)}

$\alpha-\mathrm{MSH}$ is one of melanocortins and derived from a precursor peptide encoded by the POMC gene (211). Among melanocortins and their receptors, $\alpha-\mathrm{MSH}$ and melanocortin receptor 4 (MC4R) are involved in the control of food intake in vertebrates including fish. $\alpha-\mathrm{MSH}$ or MC4R agonist inhibits food intake in the goldfish $(128,212)$ and in the rainbow trout $(129)$, suggesting that the $\alpha$ MSH/MC4R system play a role in the anorexigenic regulation of feeding in fish as in mammals. 
Although the $\alpha-\mathrm{MSH} / \mathrm{MC} 4 \mathrm{R}$ system is known to play a stimulatory role in reproduction at the level of $\mathrm{GnRH}$ neurons in mammals [see a review in Ref. (130)], available information is limited in teleost. Projection of $\alpha$-MSH fibers in the PPD of the pituitary and differential expression of POMC gene between sexually inactive and active fish in the zebrafish suggests that some of POMC-derived products are involved in the stimulation of fish reproduction $(213)$.

\section{COCAINE- AND AMPHETAMINE-REGULATED TRANSCRIPT (CART)}

CART is an anorexigenic neuropeptide originally isolated from the rat brain $(160,214)$. In fish, CART might also act as anorexigenic hormone in the goldfish (131), winter flounder (215), cod (216), channel catfish (217), zebrafish (218), and in the Atlantic salmon (219).

In mammals, CART is involved in the control of GnRH neurons. CART stimulates GnRH pulsatile release in rats $(133,134)$. The existence of close appositions between CART fibers and hypothalamic GnRH neurons in the Siberian hamster suggests the effect of CART on GnRH neuronal activity is a direct action (220).

In the catfish, the projections of CART fibers are observed in the PPD of the pituitary (221). CART is also expressed in LH cells of the catfish pituitary but only during sexual maturation period (222), suggesting its local function in the sexual maturation process. However, it should be noted that while similar expression of CART in LH cells is observed in the rat pituitary, CART inhibits the release of prolactin but not GTHs (223). Thus, the role of CART in the fish pituitary has to be examined.

\section{CHOLECYSTOKININ (CCK)}

CCK is found in the brain and in the gastrointestinal tract of various vertebrates. It has multiple biologically active forms, among which CCK-8 is the most abundant form in the brain (224). As in mammals, CCK has many physiological roles in fish, but functions primarily in the control of food intake as a satiety indicator (135).

In mammals, CCK decreases the pulse interval of $\mathrm{GnRH}$ release in goats (225). Furthermore, CCK implants into the POA, where GnRH neurons are located, increase the plasma levels of LH in rats (226). These data suggest that CCK acts at the levels of GnRH and stimulates reproduction. In fish, on the other hand, CCK seems to acts on the pituitary. An immunohistochemical study showed that CCK neurons innervate into the PPD of the pituitary and that CCK stimulates LH release in vitro in the goldfish (136).

\section{NESFATIN-1}

Nesfatin-1, a nucleobindin-2 (NUCB2) encoded unmodified peptide, was first characterized in rats (227), and was shown to have anorexigenic actions in the goldfish $(137,138)$.

The number of studies about the function of nesfatin- 1 in the control of reproduction is still limited. However, recent studies showed that nesfatin-1 acts as an inhibitory signal in the control of fish reproduction. Although nesfatin-1 plays a stimulatory role in LH secretion in rats (228), an intraperitoneal injection of nesfatin1 decreases plasma levels of $\mathrm{LH}$ in the goldfish (139). At the same time, nesfatin-1 down regulates expression of GnRH, LH $\beta$, and FSH $\beta$ genes, suggesting that the inhibitory action of nesfatin-1 takes place at the levels of GnRH neurons. Whether nesfatin-1 also functions at the level of the pituitary remains unclear.

\section{PERIPHERAL HORMONES INVOLVED IN FEEDING, METABOLISM, AND REPRODUCTION LEPTIN}

Leptin is primarily produced by adipocytes of the white adipose tissue (229), and secreted into the blood circulation in proportion to the mass of body fat. The change in plasma leptin levels is detected by the hypothalamus and thereby it acts as a peripheral factor that signals nutritional status to the CNS [see review by Crown et al. (230)]. In teleosts including the goldfish and the rainbow trout, leptin functions as a peripheral signal to inhibit food intake $(140,141,231,232)$ as in mammals (233).

In mammals, leptin stimulates the HPG axis by promoting the synthesis and release of $\mathrm{GnRH}$ from the hypothalamus, and $\mathrm{LH}$ and FSH from the pituitary (234-236). In teleosts, leptin also stimulates the reproductive axis. Leptin increases in vitro $\mathrm{LH}$ release from the pituitary culture in the sea bass (142) and the rainbow trout (143). However, it should be noted that the stimulating effect of leptin on LH release is observed only on the pituitary samples from the fish in maturational stages. Furthermore, leptin expression levels increase with the onset of sexual maturation in the Arctic char (237) and the Atlantic salmon (238). Therefore, the role of leptin in sexual maturation seems to be conserved among vertebrate species.

\section{GHRELIN}

As in mammals, ghrelin is highly expressed in the stomach and moderately in the brain $(144,239,240)$, and is involved in appetite stimulation, energy balance, feeding, and metabolism [see reviews in Ref. $(241,242)]$. Interestingly, the role of ghrelin in fish differs in different fish species. It acts as an orexigenic hormone in the goldfish (144-146) and probably in the sea bass (243) and the zebrafish (244). On the other hand, ghrelin acts as an anorexigenic hormone in the rainbow trout (147) and probably in the burbot $(245,246)$. The opposite effects of ghrelin on food intake can be explained by species-specific neural pathways mediating the effect of ghrelin (247). The variations in the role of ghrelin in feeding may reflect different regulatory mechanisms of feeding in different teleost species.

In fish species, ghrelin acts as a stimulatory factor in the reproduction, although ghrelin inhibits the HPG axis in mammals [reviewed by Tena-Sempere (248)]. Intracerebroventricular injection of ghrelin increases plasma LH levels in the goldfish (148), indicating its stimulatory action on the HPG axis. The increase of plasma LH levels is, however, small and slow compared to the increase of plasma GH levels. This suggests that the stimulatory effect of ghrelin on plasma LH levels is not through the action of ghrelin on hypothalamic GnRH. Actually, the highest levels of ghrelin receptor mRNA are observed in the sea bream and goldfish pituitary $(249,250)$. In vitro treatment with ghrelin stimulates LH release in the goldfish $(148,250)$ and in the common carp (149), while pituitary levels of mRNA for LH $\beta$ subunit is also increased. As no reports show fiber projections of hypothalamic ghrelin neurons into the pituitary in fish, ghrelin released from stomach/intestine might play a role in the LH secretion from the pituitary. Therefore, ghrelin might act as a stimulatory peripheral factor in reproduction at the level of pituitary, whereas its action on GnRH neurons is uncertain. 


\section{INTERACTIONS BETWEEN METABOLIC NEUROPEPTIDES AND THE REPRODUCTIVE SYSTEM IN THE CONTROL OF REPRODUCTION}

As shown in the above section, many metabolic neuropeptides are involved in the control of reproduction at the level of hypothalamic GnRH neurons and at the level of pituitary gonadotropes (Figure 1). Among these metabolic neuropeptides, NPY and nesfatin- 1 function as inhibitory factors on GnRH neurons, while orexin stimulates GnRH neurons. It is interesting that NPY and orexin, which possess orexigenic activity, act on the reproductive system in an opposite manner in the goldfish. It suggests that different metabolic neuropeptides might play a role in the control of reproduction under different physiological conditions. It should be noted, however, that the inhibitory role of orexin on spawning behavior and GnRH gene expression might be the result of orexin action on non-hypophysiotropic GnRH system. In the goldfish brain, hypophysiotropic GnRH type is expressed not only in the hypothalamic population but also in the olfactory bulb and midbrain populations (190). Therefore, the inhibitory effect of orexin on the HPG axis need to be confirmed although it is clear that orexin has suppressive role in some aspects of reproduction.

At the pituitary level, it is evident that many metabolic neuropeptides including NPY, MCH, GnRH2, PACAP, and CCK stimulate LH secretion. In addition, peripheral metabolic signals such as ghrelin and leptin also stimulate LH secretion at the pituitary. The fact that most central neuropeptides and peripheral metabolic signals regulate the reproductive system indicates fundamental interaction between energy balance and reproduction, which is evolutionarily conserved from fish to mammal. However, both orexigenic and anorexigenic metabolic signals act as stimulatory factors in the reproductive system in fish. In mammals, feeding and reproduction are two alternatives in general. Therefore, orexigenic factors inhibit reproduction and anorexigenic factors stimulate reproduction [see review in Ref. (251)]. In fish species, on the other hand, a central orexigenic neuropeptide NPY and a peripheral orexigenic peptide ghrelin inhibit LH secretion in the goldfish and other species (Table 1). This indicates that metabolic regulation of the reproductive system in teleost is different from that in mammals, at least in some species.

Fish species have a variety of feeding and reproductive behaviors. For example, most salmonids and the winter flounder undergo a period of fasting just before the spawning season as a part of their normal physiology (252), whereas the goldfish do not have such fasting period. The halt of food intake during final maturation might require the differential usage of metabolic signals in these species.

Recently, kisspeptin has been proposed as a mediator of metabolic signals in the mammalian reproductive system, in particular on GnRH neurons [see reviews in Ref. $(89,253)]$. In mice (254) and in the sheep (255), kisspeptin neurons in the arcuate nucleus possess leptin receptors, suggesting direct action of leptin on kisspeptin neurons. Furthermore, kisspeptin neurons receive innervations from other neurons that express leptin receptor (255). These facts suggest that leptin controls GnRH neurons through kisspeptin neurons via direct and indirect actions. Furthermore, kisspeptin neurons receive fiber projections from NPY and POMC neurons in mammals $(255,256)$. Therefore kisspeptin

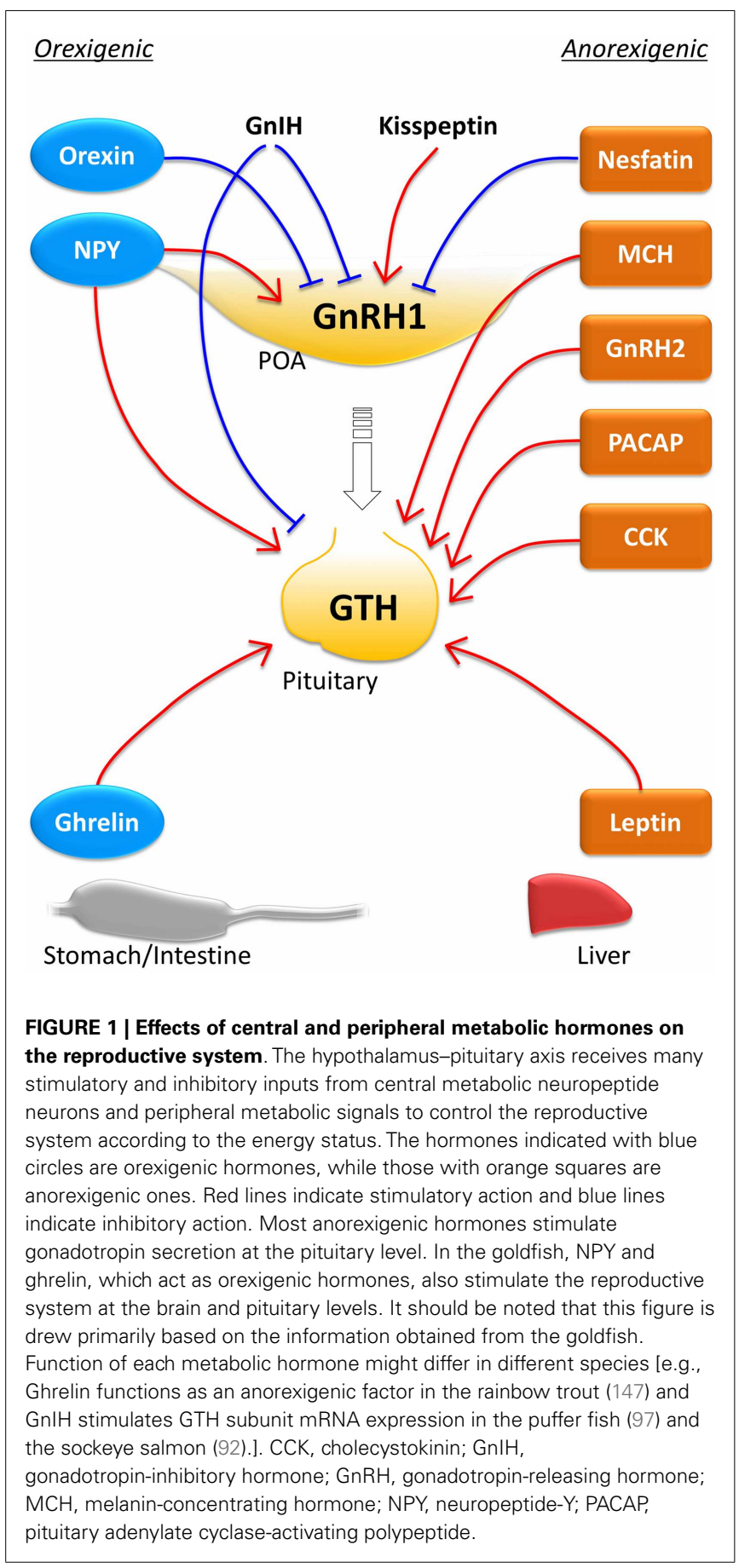

neurons might play an important role in the integration of metabolic signals to control the reproductive system. In teleost, fasting induces a significant increase in kiss 2 mRNA levels in the hypothalamus, as well as an increase in LH $\beta$ and FSH $\beta$ mRNA levels in the pituitary in the Senegalese sole (Solea senegalensis) (257), suggesting negative correlation between energy balance and reproduction. However, to our knowledge, there is no information available regarding direct evidence of metabolic regulation of kisspeptin neurons in fish. 
In addition to its primary role in reproduction, $\mathrm{GnIH}$ stimulates food intake in chickens (258) and in rats (259, 260), suggesting its potential role to switch from reproduction to feeding. Close appositions of $\mathrm{GnIH}$ fibers with NPY, orexin, $\mathrm{MCH}$, and POMC neurons in the sheep (261) indicate the involvement of several feeding regulatory pathways. However, there are no studies reporting metabolic regulation of $\mathrm{GnIH}$ neurons in vertebrates. On the other hand, GnIH is known to be regulated by stress, photoperiod, and gonadal steroids to suppress the reproductive system (89). Therefore, GnIH neurons might have a role in the modulation of feeding according to the environmental factors in mammals. Whether GnIH plays a similar role in teleosts requires more studies.

\section{INTERACTIONS AMONG NEUROPEPTIDES TO CONTROL FEEDING}

To monitor the amount of energy stock, central metabolic neuropeptide neurons receive peripheral signals including leptin and ghrelin. For example, in mammals leptin receptor is expressed in many metabolic neuropeptide neurons including orexin, NPY, GAL, MCH, POMC, CART, and CCK neurons [see reviews in Ref. $(262,263)]$. In fish species, leptin also affects several central neuropeptide neurons. Administration of leptin reduces NPY mRNA levels in the goldfish (140), grass carp (264), and in the rainbow trout $(141,265)$. On the other hand, leptin increases the mRNA levels of CCK and POMC, which are anorexigenic neuropeptides, in the goldfish (140) and the rainbow trout $(141,265)$, respectively. A recent study showed that leptin receptor knockout medaka exhibit higher levels of NPY mRNA before and after feeding and lower levels of POMC mRNA levels after feeding together with increased food intake (266). Therefore leptin's anorexigenic effect might be mediated by these neuropeptides.

Double immunostaining revealed interactions among orexigenic/anorexigenic neuropeptide neurons in teleosts, in particular in the goldfish (Figure 2). Among anorexigenic neuropeptide neurons, $\mathrm{MCH}$ neuronal fibers project to $\alpha$-MSH neurons (206) and $\alpha$-MSH neuronal fibers project to CRH neurons (267). Furthermore, a study using antagonists against $\alpha-\mathrm{MSH}$ receptor and $\mathrm{CRH}$ receptor showed that anorexigenic action of $\mathrm{MCH}$ is mediated by $\alpha$-MSH and CRH (268). In addition, GnRH2 mediates anorexigenic effect of $\alpha-\mathrm{MSH}$ and $\mathrm{CRH}$ (269). These results suggest that the MCH- $\alpha$-MSH-CRH-GnRH2 pathway suppresses food intake in the goldfish, although it is not known whether $\mathrm{CRH}$ directly acts on GnRH2 neurons.

Among orexigenic neuropeptide neurons, NPY and orexin neurons make reciprocal connections in fish as in mammals. NPY neuronal fibers make close appositions with orexin neurons, whereas orexin neuronal fibers make close appositions with NPY neurons in the NPPv in the goldfish (270). Furthermore, co-injections of OXA and NPY result in food intake higher than that observed in fish treated with NPY alone (132). These results indicate that orexins and NPY induce orexigenic actions by mutual signaling pathways in the CNS in teleost. Probably the reciprocal interaction between NPY and orexin functions as a positive-feedback system to maintain food intake.

Moreover, the orexigenic and the anorexigenic circuits are also connected with each other. $\alpha$-MSH neuronal fibers make close

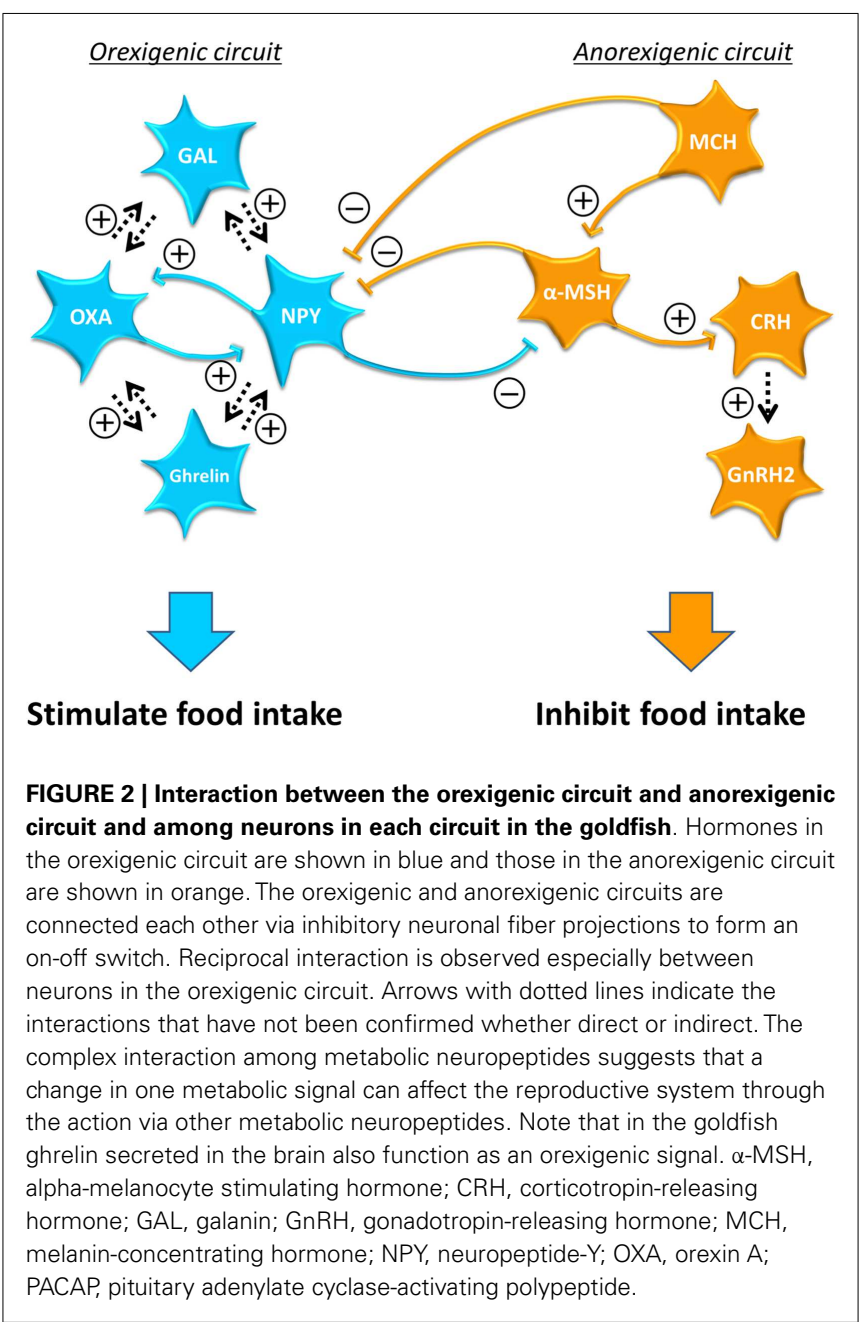

appositions with NPY neurons, whereas NPY neuronal fibers project to $\alpha$-MSH neurons in the goldfish (271). In addition, $\mathrm{MCH}$ neuronal fibers make close appositions with NPY neurons (272). These inhibitory inputs between the orexigenic and anorexigenic neurons might function as an on/off switch to decide whether eat or not eat by activating only one of the two circuits.

Studies using antagonists against of the receptors for metabolic neuropeptides further provided possible interaction among central metabolic neuropeptides in the goldfish. For example, GAL mediates the orexigenic action of orexin, and orexin mediates the orexigenic action of GAL (123). GAL also mediates NPY's action on food intake and vice versa (123). Besides, orexin mediates central action of ghrelin in food intake and central ghrelin mediates the action of orexin (273). Furthermore, NPY mediates the orexigenic action of ghrelin (274). These results indicate complex neuronal interactions especially among central orexigenic neuropeptides. This complex neuronal network suggests that many central neuropeptide neurons function in a coordinated manner to regulate food intake. To fully understand the whole circuit that controls food intake, further information on the neuronal interaction among central metabolic neuropeptides have to be obtained. 
In addition to the evident neuronal interactions in the goldfish, more combinations of neuronal interactions were reported in other fish species. In the masu salmon (275) and the Siberian sturgeon (170), NPY and GAL neurons make reciprocal connections. In the medaka, orexin and $\mathrm{MCH}$ neurons send neuronal fibers to each other (156). In the barfin flounder, reciprocal connection between orexin and $\mathrm{MCH}$ neurons and between $\alpha-\mathrm{MSH}$ and $\mathrm{MCH}$ neurons was reported (156). In the rainbow trout, $\mathrm{CRH}$ mediates the anorexigenic action of ghrelin (147). These facts suggest that the interaction among central metabolic neuropeptides is really complicated. Therefore, more fiber projection studies together with the localization of the neuropeptide receptors are necessary to understand proper relationships among these neuropeptides that consist of the regulatory circuits of food intake.

\section{PERSPECTIVES \\ DIRECT INTERACTIONS AMONG CENTRAL METABOLIC NEUROPEPTIDES AND REPRODUCTIVE SYSTEM}

Significant amount of information about the relationship among orexigenic and anorexigenic neuropeptides have been accumulated, particularly in the goldfish. However, the knowledge of direct interactions among these neurons is still not enough to draw a complete diagram of the neuronal circuit to control food intake and reproduction in fish. In particular, metabolic regulation of kisspeptin and GnRH neurons are still unknown, while it is suggested from mammalian studies. Further fiber projection studies using double immunostaining and localization of the neuropeptide receptors in certain neuronal cell bodies need to be performed.

\section{SPECIES DIFFERENCES}

There are many differences in the regulatory mechanism of food intake and reproduction not only between mammals and fish but also between fish species. The significant difference between fish species might be the result of the adaptation to a wide range of feeding habits and reproductive strategies. Therefore we have to be careful to combine data obtained from different species.

\section{SEX AND MATURATIONAL STAGES}

Several studies reported that the responses of the reproductive system to metabolic signals differ depending on the sex and the stage of sexual maturation. In fact, gonadal steroids modulate the effect of NPY on GnRH and LH release in the goldfish (276). Each study should use a particular sex and maturational stage to make comparison easy.

\section{NUTRITIONAL CONDITIONS}

Animals might change the metabolic control of reproduction according to the available energy stock. For example, short term food limitation attenuates sexual motivation, while remaining energy stock still maintains activity of the HPG axis. On the other hand, long term food limitation depletes the energy stock and stops the HPG axis to prioritize the energy supply to the survival. Thus, feeding conditions and the timing of experiment might be important to obtain comparable data.

\section{ENDOCANNABINOID SYSTEM}

The endocannabinoid system is involved in a variety of physiology including pain-sensation, mood, and memory. Importantly, both energy balance and reproduction are modulated by the endocannabinoid system. Endocannabinoids modulate several hypothalamic metabolic neuropeptides in mammals [see reviews in Ref. $(277,278)]$. The endocannabinoid system also regulates food intake in fish $(279,280)$. In mammalian and non-mammalian vertebrates, the endocannabinoid system regulates hypothalamic GnRH neurons and pituitary LH cells directly and indirectly [see reviews in Ref. $(281,282)]$. Interrelation among these systems might be an additional mechanism underlying the interaction between mood, stress, appetite, and reproduction.

\section{CONCLUSION}

In summary, the cellular and molecular basis for the integration of feeding and reproduction involves a complex interaction of the reproductive system with metabolic neuropeptides and peripheral fuels. The metabolic neuropeptides, particularly orexin, NPY, PACAP, MCH, nesfatin, GnRH2, and CCK play an important role in the reproduction by either regulating GnRH neurons in the hypothalamus or by stimulating gonadotropes in the pituitary. Peripheral metabolic signals such as ghrelin and leptin also act on the pituitary to stimulate LH secretion. It should be, however, noted that compared to mammals, fishes show a great variety of feeding and reproductive habits. The variations of metabolic control of reproduction in different teleost species may reflect different requirement of energy status for reproduction in different species. Compared to mammals, fish represent a vast phylogenetic group, which shows a significant level of diversity with regards to morphology, ecology, behavior, and genomes (283). Thus, species differences in the neuroendocrine control of reproduction have to be taken into consideration in teleosts. In addition, more detailed studies about the interconnections among metabolic neuropeptide neurons, effects of sexual maturation, and nutritional conditions will provide more precise figure of the metabolic control of reproduction. Furthermore, differential control of multiple $\mathrm{GnRH}$ neuronal population by the neuropeptides and metabolic signals should be examined to elucidate their roles in different aspects of metabolic control of reproduction.

\section{ACKNOWLEDGMENTS}

This work was supported by grants from Monash University Malaysia, MM-2-5-06, MM-7-07, and MCG006 (to Ishwar S. Parhar), M-3-07 and M-3-08 (to Takashi Kitahashi).

\section{REFERENCES}

1. Schneider JE. Energy balance and reproduction. Physiol Behav (2004) 81(2):289-317. doi:10.1016/j.physbeh.2004.02.007

2. Fernandez-Fernandez R, Martini AC, Navarro VM, Castellano JM, Dieguez C, Aguilar E, et al. Novel signals for the integration of energy balance and reproduction. Mol Cell Endocrinol (2006) 254-5:127-32. doi:10.1016/j.mce. 2006.04.026

3. Castellano JM, Roa J, Luque RM, Dieguez C, Aguilar E, Pinilla L, et al. KiSS1/kisspeptins and the metabolic control of reproduction: physiologic roles and putative physiopathological implications. Peptides (2009) 30(1):139-45. doi:10.1016/j.peptides.2008.06.007

4. Hill JW, Elmquist JK, Elias CF. Hypothalamic pathways linking energy balance and reproduction. Am J Physiol Endocrinol Metab (2008) 294(5):E827-32. doi:10.1152/ajpendo.00670.2007

5. Schneider JE, Buckley CA, Blum RM, Zhou D, Szymanski L, Day DE, et al. Metabolic signals, hormones and neuropeptides involved in control of 
energy balance and reproductive success in hamsters. Eur J Neurosci (2002) 16(3):377-9. doi:10.1046/j.1460-9568.2002.02118.x

6. Wade GN, Schneider JE, Li HY. Control of fertility by metabolic cues. Am J Physiol (1996) 270(1 Pt 1):E1-19.

7. Volkoff H, Canosa LF, Unniappan S, Cerda-Reverter JM, Bernier NJ, Kelly SP, et al. Neuropeptides and the control of food intake in fish. Gen Comp Endocrinol (2005) 142(1-2):3-19. doi:10.1016/j.ygcen.2004.11.001

8. Mircea CN, Lujan ME, Pierson RA. Metabolic fuel and clinical implications for female reproduction. J Obstet Gynaecol Can (2007) 29(11):887-902.

9. Volkoff H, Xu M, MacDonald E, Hoskins L. Aspects of the hormonal regulation of appetite in fish with emphasis on goldfish, Atlantic cod and winter flounder: notes on actions and responses to nutritional, environmental and reproductive changes. Comp Biochem Physiol A Mol Integr Physiol (2009) 153(1):8-12. doi:10.1016/j.cbpa.2008.12.001

10. Yaron Z, Gur G, Melamed P, Rosenfeld H, Elizur A, Levavi-Sivan B. Regulation of fish gonadotropins. Int Rev Cytol (2003) 225:131-85. doi:10.1016/S00747696(05)25004-0

11. Zohar Y, Munoz-Cueto JA, Elizur A, Kah O. Neuroendocrinology of reproduction in teleost fish. Gen Comp Endocrinol (2010) 165(3):438-55. doi:10.1016/ j.ygcen.2009.04.017

12. Amoss M, Burgus R, Blackwell R, Vale W, Fellows R, Guillemin R. Purification, amino acid composition and $\mathrm{N}$-terminus of the hypothalamic luteinizing hormone releasing factor (LRF) of ovine origin. Biochem Biophys Res Commun (1971) 44(1):205-10. doi:10.1016/S0006-291X(71)80179-1

13. Matsuo H, Baba Y, Nair RM, Arimura A, Schally AV. Structure of the porcine LH- and FSH-releasing hormone. I. The proposed amino acid sequence. Biochem Biophys Res Commun (1971) 43(6):1334-9. doi:10.1016/ S0006-291X(71)80019-0

14. Breton B, Jalabert B, Billard R, Weil C. In vitro stimulation of the release of pituitary gonadotropic hormone by a hypothalamic factor in the carp Cyprinus carpio L. C R Acad Sci Hebd Seances Acad Sci D (1971) 273(25):2591-4.

15. Sherwood N, Eiden L, Brownstein M, Spiess J, Rivier J, Vale W. Characterization of a teleost gonadotropin-releasing hormone. Proc Natl Acad Sci U S A (1983) 80(9):2794-8. doi:10.1073/pnas.80.9.2794

16. Sherwood NM, Zoeller RT, Moore FL. Multiple forms of gonadotropinreleasing hormone in amphibian brains. Gen Comp Endocrinol (1986) 61(2):313-22. doi:10.1016/0016-6480(86)90208-X

17. Miyamoto K, Hasegawa Y, Minegishi T, Nomura M, Takahashi Y, Igarashi $\mathrm{M}$, et al. Isolation and characterization of chicken hypothalamic luteinizing hormone-releasing hormone. Biochem Biophys Res Commun (1982) 107(3):820-7. doi:10.1016/0006-291X(82)90596-4

18. Miyamoto K, Hasegawa Y, Nomura M, Igarashi M, Kangawa K, Matsuo H. Identification of the second gonadotropin-releasing hormone in chicken hypothalamus: evidence that gonadotropin secretion is probably controlled by two distinct gonadotropin-releasing hormones in avian species. Proc Natl Acad Sci U S A (1984) 81(12):3874-8. doi:10.1073/pnas.81.12.3874

19. Lovejoy DA, Stell WK, Sherwood NM. Partial characterization of four forms of immunoreactive gonadotropin-releasing hormone in the brain and terminal nerve of the spiny dogfish (Elasmobranchii; Squalus acanthias). Regul Pept (1992) 37(1):39-48. doi:10.1016/0167-0115(92)90062-Y

20. Ngamvongchon S, Rivier JE, Sherwood NM. Structure-function studies of five natural, including catfish and dogfish, gonadotropin-releasing hormones and eight analogs on reproduction in Thai catfish (Clarias macrocephalus). Regul Pept (1992) 42(1-2):63-73. doi:10.1016/0167-0115(92)90024-O

21. Sower SA, Chiang YC, Lovas S, Conlon JM. Primary structure and biological activity of a third gonadotropin-releasing hormone from lamprey brain. Endocrinology (1993) 132(3):1125-31. doi:10.1210/endo.132.3.8440174

22. Jimenez-Linan M, Rubin BS, King JC. Examination of guinea pig luteinizing hormone-releasing hormone gene reveals a unique decapeptide and existence of two transcripts in the brain. Endocrinology (1997) 138(10):4123-30. doi:10.1210/en.138.10.4123

23. Carolsfeld J, Powell JF, Park M, Fischer WH, Craig AG, Chang JP, et al. Primary structure and function of three gonadotropin-releasing hormones, including a novel form, from an ancient teleost, herring. Endocrinology (2000) 141(2):505-12. doi:10.1210/endo.141.2.7300

24. Kavanaugh SI, Nozaki M, Sower SA. Origins of gonadotropin-releasing hormone $(\mathrm{GnRH})$ in vertebrates: identification of a novel $\mathrm{GnRH}$ in a basal vertebrate, the sea lamprey. Endocrinology (2008) 149(8):3860-9. doi:10.1210/en. 2008-0184
25. Adams BA, Vickers ED, Warby C, Park M, Fischer WH, Grey Craig A, et al. Three forms of gonadotropin-releasing hormone, including a novel form, in a basal salmonid, Coregonus clupeaformis. Biol Reprod (2002) 67(1):232-9. doi:10.1095/biolreprod67.1.232

26. Montaner AD, Mongiat L, Lux-Lantos VA, Park MK, Fischer WH, Craig AG, et al. Structure and biological activity of gonadotropin-releasing hormone isoforms isolated from rat and hamster brains. Neuroendocrinology (2001) 74(3):202-12. doi:10.1159/000054687

27. Mohamed JS, Khan IA. Molecular cloning and differential expression of three GnRH mRNAs in discrete brain areas and lymphocytes in red drum. J Endocrinol (2006) 188(3):407-16. doi:10.1677/joe.1.06423

28. Andersson E, Fjelldal PG, Klenke U, Vikingstad E, Taranger GL, Zohar $\mathrm{Y}$, et al. Three forms of GnRH in the brain and pituitary of the turbot, Scophthalmus maximus: immunological characterization and seasonal variation. Comp Biochem Physiol B Biochem Mol Biol (2001) 129(2-3):551-8. doi:10.1016/S1096-4959(01)00363-3

29. Okubo K, Amano M, Yoshiura Y, Suetake H, Aida K. A novel form of gonadotropin-releasing hormone in the medaka, Oryzias latipes. Biochem Biophys Res Commun (2000) 276(1):298-303. doi:10.1006/bbrc.2000.3476

30. Sherwood NM, von Schalburg KR, Lescheid DW. Origin and evolution of GnRH in vertebrates and invertebrates. In: Parhar IS, Sakuma Y, editors. GnRH Neurons: From Genes to Behavior. Tokyo: Brain Shuppan (1997). p. 3-25.

31. Parhar IS. GnRH in tilapia: three genes, three origins and their roles. In: Parhar IS, Sakuma Y, editors. GnRH Neurons: Gene to Behavior. Tokyo: Brain Shuppan (1997). p. 99-122.

32. Parhar IS. Cell migration and evolutionary significance of GnRH subtypes. Prog Brain Res (2002) 141:3-17. doi:10.1016/S0079-6123(02)41080-1

33. Millar RP, Lu ZL, Pawson AJ, Flanagan CA, Morgan K, Maudsley SR. Gonadotropin-releasing hormone receptors. Endocr Rev (2004) 25(2):235-75. doi:10.1210/er.2003-0002

34. Karigo T, Oka Y. Neurobiological study of fish brains gives insights into the nature of gonadotropin-releasing hormone 1-3 neurons. Front Endocrinol (2013) 4:177. doi:10.3389/fendo.2013.00177

35. Powell JF, Zohar Y, Elizur A, Park M, Fischer WH, Craig AG, et al. Three forms of gonadotropin-releasing hormone characterized from brains of one species. Proc Natl Acad Sci U S A (1994) 91(25):12081-5. doi:10.1073/pnas.91.25.12081

36. Okubo K, Nagahama Y. Structural and functional evolution of gonadotropinreleasing hormone in vertebrates. Acta Physiol (2008) 193(1):3-15. doi:10. 1111/j.1748-1716.2008.01832.x

37. White SA, Kasten TL, Bond CT, Adelman JP, Fernald RD. Three gonadotropinreleasing hormone genes in one organism suggest novel roles for an ancient peptide. Proc Natl Acad Sci U S A (1995) 92(18):8363-7. doi:10.1073/pnas.92. 18.8363

38. Gothilf Y, Munoz-Cueto JA, Sagrillo CA, Selmanoff M, Chen TT, Kah O, et al. Three forms of gonadotropin-releasing hormone in a perciform fish (Sparus aurata): complementary deoxyribonucleic acid characterization and brain localization. Biol Reprod (1996) 55(3):636-45. doi:10.1095/biolreprod55.3.636

39. Gonzalez-Martinez D, Madigou T, Zmora N, Anglade I, Zanuy S, Zohar Y, et al. Differential expression of three different prepro-GnRH (gonadotropinreleasing hormone) messengers in the brain of the European sea bass (Dicentrarchus labrax). J Comp Neurol (2001) 429(1):144-55. doi:10.1002/10969861(20000101)429:1<144::AID-CNE11>3.0.CO;2-B

40. Gonzalez-Martinez D, Zmora N, Mananos E, Saligaut D, Zanuy S, Zohar Y, et al. Immunohistochemical localization of three different prepro-GnRHs in the brain and pituitary of the European sea bass (Dicentrarchus labrax) using antibodies to the corresponding GnRH-associated peptides. J Comp Neurol (2002) 446(2):95-113. doi:10.1002/cne.10190

41. Palevitch O, Kight K, Abraham E, Wray S, Zohar Y, Gothilf Y. Ontogeny of the GnRH systems in zebrafish brain: in situ hybridization and promoter-reporter expression analyses in intact animals. Cell Tissue Res (2007) 327(2):313-22. doi:10.1007/s00441-006-0279-0

42. Vickers ED, Laberge F, Adams BA, Hara TJ, Sherwood NM. Cloning and localization of three forms of gonadotropin-releasing hormone, including the novel whitefish form, in a salmonid, Coregonus clupeaformis. Biol Reprod (2004) 70(4):1136-46. doi:10.1095/biolreprod.103.023846

43. Pandolfi M, Munoz-Cueto JA, Lo Nostro FL, Downs JL, Paz DA, Maggese MC, et al. GnRH systems of Cichlasoma dimerus (Perciformes, Cichlidae) revisited: a localization study with antibodies and riboprobes to $\mathrm{GnRH}$-associated peptides. Cell Tissue Res (2005) 321(2):219-32. doi:10.1007/s00441-004-1055-7 
44. Mohamed JS, Thomas P, Khan IA. Isolation, cloning, and expression of three prepro-GnRH mRNAs in Atlantic croaker brain and pituitary. J Comp Neurol (2005) 488(4):384-95. doi:10.1002/cne.20596

45. Parhar IS, Iwata M. Gonadotropin releasing hormone $(\mathrm{GnRH})$ neurons project to growth hormone and somatolactin cells in the steelhead trout. Histochemistry (1994) 102(3):195-203. doi:10.1007/BF00268896

46. Breton B, Govoroun M, Mikolajczyk T. GTH I and GTH II secretion profiles during the reproductive cycle in female rainbow trout: relationship with pituitary responsiveness to GnRH-A stimulation. Gen Comp Endocrinol (1998) 111(1):38-50. doi:10.1006/gcen.1998.7088

47. Mananos EL, Anglade I, Chyb J, Saligaut C, Breton B, Kah O. Involvement of gamma-aminobutyric acid in the control of GTH-1 and GTH-2 secretion in male and female rainbow trout. Neuroendocrinology (1999) 69(4):269-80. doi:10.1159/000054428

48. Weil C, Carre F, Blaise O, Breton B, Le Bail PY. Differential effect of insulinlike growth factor I on in vitro gonadotropin (I and II) and growth hormone secretions in rainbow trout (Oncorhynchus mykiss) at different stages of the reproductive cycle. Endocrinology (1999) 140(5):2054-62. doi:10.1210/endo. 140.5.6747

49. Dickey JT, Swanson P. Effects of sex steroids on gonadotropin (FSH and LH) regulation in Coho salmon (Oncorhynchus kisutch). J Mol Endocrinol (1998) 21(3):291-306. doi:10.1677/jme.0.0210291

50. Senthilkumaran B, Okuzawa K, Gen K, Ookura T, Kagawa H. Distribution and seasonal variations in levels of three native GnRHs in the brain and pituitary of perciform fish. J Neuroendocrinol (1999) 11(3):181-6. doi:10.1046/j.13652826.1999.00304.x

51. Holland MC, Hassin S, Zohar Y. Seasonal fluctuations in pituitary levels of the three forms of gonadotropin-releasing hormone in striped bass, Morone saxatilis (Teleostei), during juvenile and pubertal development. J Endocrinol (2001) 169(3):527-38. doi:10.1677/joe.0.1690527

52. Amano M, Okubo K, Yamanome T, Yamada H, Aida K, Yamamori K. Changes in brain GnRH mRNA and pituitary GnRH peptide during testicular maturation in barfin flounder. Comp Biochem Physiol B Biochem Mol Biol (2004) 138(4):435-43. doi:10.1016/j.cbpc.2004.05.005

53. Amano M, Pham KX, Amiya N, Yamanome T, Yamamori K. Changes in brain seabream GnRH mRNA and pituitary seabream GnRH peptide levels during ovarian maturation in female barfin flounder. Gen Comp Endocrinol (2008) 158(2):168-72. doi:10.1016/j.ygcen.2008.06.008

54. Okuzawa K, Gen K, Bruysters M, Bogerd J, Gothilf Y, Zohar Y, et al. Seasonal variation of the three native gonadotropin-releasing hormone messenger ribonucleic acids levels in the brain of female red seabream. Gen Comp Endocrinol (2003) 130(3):324-32. doi:10.1016/S0016-6480(02)00629-9

55. Okubo K, Sakai F, Lau EL, Yoshizaki G, Takeuchi Y, Naruse K, et al. Forebrain gonadotropin-releasing hormone neuronal development: insights from transgenic medaka and the relevance to X-linked Kallmann syndrome. Endocrinology (2006) 147(3):1076-84. doi:10.1210/en.2005-0468

56. Holland MC, Gothilf Y, Meiri I, King JA, Okuzawa K, Elizur A, et al. Levels of the native forms of GnRH in the pituitary of the gilthead seabream, Sparus aurata, at several characteristic stages of the gonadal cycle. Gen Comp Endocrinol (1998) 112(3):394-405. doi:10.1006/gcen.1998.7138

57. Zandbergen MA, Kah O, Bogerd J, Peute J, Goos HJ. Expression and distribution of two gonadotropin-releasing hormones in the catfish brain. Neuroendocrinology (1995) 62(6):571-8. doi:10.1159/000127052

58. Amano M, Oka Y, Yamanome T, Okuzawa K, Yamamori K. Three GnRH systems in the brain and pituitary of a pleuronectiform fish, the barfin flounder Verasper moseri. Cell Tissue Res (2002) 309(2):323-9. doi:10.1007/s00441-0020594-z

59. Lethimonier C, Madigou T, Munoz-Cueto JA, Lareyre JJ, Kah O. Evolutionary aspects of GnRHs, GnRH neuronal systems and GnRH receptors in teleost fish. Gen Comp Endocrinol (2004) 135(1):1-16. doi:10.1016/j.ygcen.2003.10.007

60. Yamamoto N, Oka Y, Kawashima S. Lesions of gonadotropin-releasing hormone-immunoreactive terminal nerve cells: effects on the reproductive behavior of male dwarf gouramis. Neuroendocrinology (1997) 65(6):403-12. doi:10.1159/000127203

61. Kitahashi T, Sato A, Alok D, Kaeriyama M, Zohar Y, Yamauchi K, et al. Gonadotropin-releasing hormone analog and sex steroids shorten homing duration of sockeye salmon in Lake Shikotsu. Zoolog Sci (1998) 15(5):767-71. doi:10.2108/zsj.15.767
62. Ogawa S, Akiyama G, Kato S, Soga T, Sakuma Y, Parhar IS. Immunoneutralization of gonadotropin-releasing hormone type-III suppresses male reproductive behavior of cichlids. Neurosci Lett (2006) 403(3):201-5. doi:10.1016/j.neulet. 2006.02.041

63. Umino O, Dowling JE. Dopamine release from interplexiform cells in the retina: effects of GnRH, FMRFamide, bicuculline, and enkephalin on horizontal cell activity. J Neurosci (1991) 11(10):3034-46.

64. Walker SE, Stell WK. Gonadotropin-releasing hormone (GnRF), molluscan cardioexcitatory peptide (FMRFamide), enkephalin and related neuropeptides affect goldfish retinal ganglion cell activity. Brain Res (1986) 384(2):262-73. doi:10.1016/0006-8993(86)91162-5

65. Eisthen HL, Delay RJ, Wirsig-Wiechmann CR, Dionne VE. Neuromodulatory effects of gonadotropin releasing hormone on olfactory receptor neurons. J Neurosci (2000) 20(11):3947-55.

66. Saito D, Hasegawa Y, Urano A. Gonadotropin-releasing hormones modulate electrical activity of vasotocin and isotocin neurons in the brain of rainbow trout. Neurosci Lett (2003) 351(2):107-10. doi:10.1016/j.neulet.2003.08.017

67. Kinoshita M, Kobayashi S, Urano A, Ito E. Neuromodulatory effects of gonadotropin-releasing hormone on retinotectal synaptic transmission in the optic tectum of rainbow trout. Eur J Neurosci (2007) 25(2):480-4. doi:10.1111/j.1460-9568.2006.05294.x

68. Oka Y. Three types of gonadotrophin-releasing hormone neurones and steroidsensitive sexually dimorphic kisspeptin neurones in teleosts. J Neuroendocrinol (2009) 21(4):334-8. doi:10.1111/j.1365-2826.2009.01850.x

69. Amano M, Urano A, Aida K. Distribution and function of gonadotropinreleasing hormone $(\mathrm{GnRH})$ in the teleost brain. Zoolog Sci (1997) 14(1):1-11. doi:10.2108/zsj.14.1

70. Abraham E, Palevitch O, Gothilf Y, Zohar Y. The zebrafish as a model system for forebrain GnRH neuronal development. Gen Comp Endocrinol (2009) 164(2-3):151-60. doi:10.1016/j.ygcen.2009.01.012

71. Parhar IS, Tosaki H, Sakuma Y, Kobayashi M. Sex differences in the brain of goldfish: gonadotropin-releasing hormone and vasotocinergic neurons. Neuroscience (2001) 104(4):1099-110. doi:10.1016/S0306-4522(01)00153-1

72. Oakley AE, Clifton DK, Steiner RA. Kisspeptin signaling in the brain. Endocr $\operatorname{Rev}(2009)$ 30(6):713-43. doi:10.1210/er.2009-0005

73. Kotani M, Detheux M, Vandenbogaerde A, Communi D, Vanderwinden JM, Le Poul E, et al. The metastasis suppressor gene KiSS-1 encodes kisspeptins, the natural ligands of the orphan $\mathrm{G}$ protein-coupled receptor GPR54. J Biol Chem (2001) 276(37):34631-6. doi:10.1074/jbc.M104847200

74. Kitahashi T, Ogawa S, Parhar IS. Cloning and expression of kiss 2 in the zebrafish and medaka. Endocrinology (2009) 150(2):821-31. doi:10.1210/en.2008-0940

75. Felip A, Zanuy S, Pineda R, Pinilla L, Carrillo M, Tena-Sempere M, et al. Evidence for two distinct KiSS genes in non-placental vertebrates that encode kisspeptins with different gonadotropin-releasing activities in fish and mammals. Mol Cell Endocrinol (2009) 312(1-2):61-71. doi:10.1016/j.mce. 2008.11.017

76. Li S, Zhang Y, Liu Y, Huang X, Huang W, Lu D, et al. Structural and functional multiplicity of the kisspeptin/GPR54 system in goldfish (Carassius auratus). J Endocrinol (2009) 201(3):407-18. doi:10.1677/joe-09-0016

77. Lee YR, Tsunekawa K, Moon MJ, Um HN, Hwang JI, Osugi T, et al. Molecular evolution of multiple forms of kisspeptins and GPR54 receptors in vertebrates. Endocrinology (2009) 150(6):2837-46. doi:10.1210/en.2008-1679

78. Biran J, Ben-Dor S, Levavi-Sivan B. Molecular identification and functional characterization of the kisspeptin/kisspeptin receptor system in lower vertebrates. Biol Reprod (2008) 79(4):776-86. doi:10.1095/biolreprod.107.066266

79. Mechaly AS, Vinas J, Piferrer F. Identification of two isoforms of the Kisspeptin1 receptor (kisslr) generated by alternative splicing in a modern teleost, the Senegalese sole (Solea senegalensis). Biol Reprod (2009) 80(1):60-9. doi:10. 1095/biolreprod.108.072173

80. Shi Y, Zhang Y, Li S, Liu Q, Lu D, Liu M, et al. Molecular identification of the Kiss2/Kiss1ra system and its potential function during 17alphamethyltestosterone-induced sex reversal in the orange-spotted grouper, Epinephelus coioides ${ }^{1}$. Biol Reprod (2010) 83(1):63-74. doi:10.1095/biolreprod. 109.080044

81. Shahjahan M, Motohashi E, Doi H, Ando H. Elevation of Kiss2 and its receptor gene expression in the brain and pituitary of grass puffer during the spawning season. Gen Comp Endocrinol (2010) 169(1):48-57. doi:10.1016/j.ygcen.2010. 07.008 
82. Mechaly AS, Vinas J, Murphy C, Reith M, Piferrer F. Gene structure of the Kiss1 receptor-2 (Kiss1r-2) in the Atlantic halibut: insights into the evolution and regulation of Kiss1r genes. Mol Cell Endocrinol (2010) 317(1-2):78-89. doi:10.1016/j.mce.2009.11.005

83. Yang B, Jiang Q, Chan T, Ko WKW, Wong AOL. Goldfish kisspeptin: molecular cloning, tissue distribution of transcript expression, and stimulatory effects on prolactin, growth hormone and luteinizing hormone secretion and gene expression via direct actions at the pituitary level. Gen Comp Endocrinol (2010) 165(1):60-71. doi:10.1016/j.ygcen.2009.06.001

84. Kanda S, Akazome Y, Matsunaga T, Yamamoto N, Yamada S, Tsukamura H, et al. Identification of KiSS-1 product kisspeptin and steroid-sensitive sexually dimorphic kisspeptin neurons in medaka (Oryzias latipes). Endocrinology (2008) 149(5):2467-76. doi:10.1210/en.2007-1503

85. Servili A, Le Page Y, Leprince J, Caraty A, Escobar S, Parhar IS, et al. Organization of two independent kisspeptin systems derived from evolutionary-ancient kiss genes in the brain of zebrafish. Endocrinology (2011) 152(4):1527-40. doi:10.1210/en.2010-0948

86. Parhar IS, Ogawa S, Sakuma Y. Laser-captured single digoxigenin-labeled neurons of gonadotropin-releasing hormone types reveal a novel $G$ proteincoupled receptor (Gpr54) during maturation in cichlid fish. Endocrinology (2004) 145(8):3613-8. doi:10.1210/en.2004-0395

87. Ogawa S, Ng KW, Ramadasan PN, Nathan FM, Parhar IS. Habenular Kiss1 neurons modulate the serotonergic system in the brain of zebrafish. Endocrinology (2012) 153(5):2398-407. doi:10.1210/en.2012-1062

88. Tsutsui K, Saigoh E, Ukena K, Teranishi H, Fujisawa Y, Kikuchi M, et al. A novel avian hypothalamic peptide inhibiting gonadotropin release. Biochem Biophys Res Commun (2000) 275(2):661-7. doi:10.1006/bbrc.2000.3350

89. Parhar I, Ogawa S, Kitahashi T. RFamide peptides as mediators in environmental control of GnRH neurons. Prog Neurobiol (2012) 98(2):176-96. doi:10.1016/j.pneurobio.2012.05.011

90. Tsutsui K, Ubuka T, Bentley GE, Kriegsfeld LJ. Gonadotropin-inhibitory hormone (GnIH): discovery, progress and prospect. Gen Comp Endocrinol (2012) 177(3):305-14. doi:10.1016/j.ygcen.2012.02.013

91. Sawada K, Ukena K, Satake H, Iwakoshi E, Minakata H, Tsutsui K. Novel fish hypothalamic neuropeptide. Eur J Biochem (2002) 269(24):6000-8. doi:10. 1046/j.1432-1033.2002.03351.x

92. Amano M, Moriyama S, Iigo M, Kitamura S, Amiya N, Yamamori K, et al. Novel fish hypothalamic neuropeptides stimulate the release of gonadotrophins and growth hormone from the pituitary of sockeye salmon. J Endocrinol (2006) 188(3):417-23. doi:10.1677/joe.1.06494

93. Moussavi M, Wlasichuk M, Chang JP, Habibi HR. Seasonal effect of GnIH on gonadotrope functions in the pituitary of goldfish. Mol Cell Endocrinol (2012) 350(1):53-60. doi:10.1016/j.mce.2011.11.020

94. Zhang Y, Li S, Liu Y, Lu D, Chen H, Huang X, et al. Structural diversity of the GnIH/GnIH receptor system in teleost: its involvement in early development and the negative control of LH release. Peptides (2010) 31(6):1034-43. doi:10.1016/j.peptides.2010.03.003

95. Qi X, Zhou W, Li S, Lu D, Yi S, Xie R, et al. Evidences for the regulation of $\mathrm{GnRH}$ and GTH expression by GnIH in the goldfish, Carassius auratus. Mol Cell Endocrinol (2013) 366(1):9-20. doi:10.1016/j.mce.2012.11.001

96. Qi X, Zhou W, Lu D, Wang Q, Zhang H, Li S, et al. Sexual dimorphism of steroidogenesis regulated by $\mathrm{GnIH}$ in the goldfish, Carassius auratus. Biol Reprod (2013) 88(4):89. doi:10.1095/biolreprod.112.105114

97. Shahjahan M, Ikegami T, Osugi T, Ukena K, Doi H, Hattori A, et al. Synchronised expressions of LPXRFamide peptide and its receptor genes: seasonal, diurnal and circadian changes during spawning period in grass puffer. $\mathrm{J} \mathrm{Neu-}$ roendocrinol (2011) 23(1):39-51. doi:10.1111/j.1365-2826.2010.02081.x

98. Ubuka T, Inoue K, Fukuda Y, Mizuno T, Ukena K, Kriegsfeld LJ, et al. Identification, expression, and physiological functions of Siberian hamster gonadotropin-inhibitory hormone. Endocrinology (2012) 153(1):373-85. doi: 10.1210/en.2011-1110

99. Umatani C, Abe H, Oka Y. Neuropeptide RFRP inhibits the pacemaker activity of terminal nerve GnRH neurons. J Neurophysiol (2013) 109(9):2354-63. doi:10.1152/jn.00712.2012

100. Yokobori E, Kojima K, Azuma M, Kang KS, Maejima S, Uchiyama M, et al. Stimulatory effect of intracerebroventricular administration of orexin A on food intake in the zebrafish, Danio rerio. Peptides (2011) 32(7):1357-62. doi:10.1016/j.peptides.2011.05.010
101. Facciolo RM, Crudo M, Giusi G, Alo R, Canonaco M. Light- and darkdependent orexinergic neuronal signals promote neurodegenerative phenomena accounting for distinct behavioral responses in the teleost Thalassoma pavo. J Neurosci Res (2009) 87(3):748-57. doi:10.1002/jnr.21886

102. Hoskins LJ, Xu M, Volkoff $\mathrm{H}$. Interactions between gonadotropin-releasing hormone $(\mathrm{GnRH})$ and orexin in the regulation of feeding and reproduction in goldfish (Carassius auratus). Horm Behav (2008) 54(3):379-85. doi:10.1016/j. yhbeh.2008.04.011

103. Lopez-Patino MA, Guijarro AI, Isorna E, Delgado MJ, Alonso-Bedate M, de Pedro N. Neuropeptide Y has a stimulatory action on feeding behavior in goldfish (Carassius auratus). Eur J Pharmacol (1999) 377(2-3):147-53. doi:10.1016/S0014-2999(99)00408-2

104. Aldegunde M, Mancebo M. Effects of neuropeptide $Y$ on food intake and brain biogenic amines in the rainbow trout (Oncorhynchus mykiss). Peptides (2006) 27(4):719-27. doi:10.1016/j.peptides.2005.09.014

105. Matsuda K. Recent advances in the regulation of feeding behavior by neuropeptides in fish. Ann N Y Acad Sci (2009) 1163:241-50. doi:10.1111/j.17496632.2008.03619.x

106. Yokobori E, Azuma M, Nishiguchi R, Kang KS, Kamijo M, Uchiyama $\mathrm{M}$, et al. Neuropeptide $\mathrm{Y}$ stimulates food intake in the zebrafish, Danio rerio. J Neuroendocrinol (2012) 24(5):766-73. doi:10.1111/j.1365-2826.2012. 02281.x

107. Peng C, Humphries S, Peter RE, Rivier JE, Blomqvist AG, Larhammar D. Actions of goldfish neuropeptide $\mathrm{Y}$ on the secretion of growth hormone and gonadotropin-II in female goldfish. Gen Comp Endocrinol (1993) 90(3):306-17. doi:10.1006/gcen.1993.1086

108. Peng C, Chang JP, Yu KL, Wong AO, Van Goor F, Peter RE, et al. Neuropeptide-Y stimulates growth hormone and gonadotropin-II secretion in the goldfish pituitary: involvement of both presynaptic and pituitary cell actions. Endocrinology (1993) 132(4):1820-9. doi:10.1210/endo.132.4.8462479

109. Breton B, Mikolajczyk T, Popek W, Bieniarz K, Epler P. Neuropeptide Y stimulates in vivo gonadotropin secretion in teleost fish. Gen Comp Endocrinol (1991) 84(2):277-83. doi:10.1016/0016-6480(91)90050-G

110. Senthilkumaran B, Okuzawa K, Gen K, Kagawa H. Effects of serotonin, GABA and neuropeptide $\mathrm{Y}$ on seabream gonadotropin releasing hormone release in vitro from preoptic-anterior hypothalamus and pituitary of red seabream, Pagrus major. J Neuroendocrinol (2001) 13(5):395-400. doi:10.1046/j.13652826.2001.00645.x

111. Cerda-Reverter JM, Sorbera LA, Carrillo M, Zanuy S. Energetic dependence of NPY-induced LH secretion in a teleost fish (Dicentrarchus labrax). Am J Physiol (1999) 277(6 Pt 2):R1627-34.

112. Matsuda K, Maruyama K, Nakamachi T, Miura T, Uchiyama M, Shioda S. Inhibitory effects of pituitary adenylate cyclase-activating polypeptide (PACAP) and vasoactive intestinal peptide (VIP) on food intake in the goldfish, Carassius auratus. Peptides (2005) 26(9):1611-6. doi:10.1016/j.peptides.2005. 02.022

113. Sawisky GR, Chang JP. Intracellular calcium involvement in pituitary adenylate cyclase-activating polypeptide stimulation of growth hormone and gonadotrophin secretion in goldfish pituitary cells. J Neuroendocrinol (2005) 17(6):353-71. doi:10.1111/j.1365-2826.2005.01312.x

114. Chang JP, Wirachowsky NR, Kwong P, Johnson JD. Pacap stimulation of gonadotropin-II secretion in goldfish pituitary cells: mechanisms of action and interaction with gonadotropin releasing hormone signalling. J Neuroendocrinol (2001) 13(6):540-50. doi:10.1046/j.1365-2826.2001.00667.x

115. Yaron Z, Gur G, Melamed P, Rosenfeld H, Levavi-Sivan B, Elizur A. Regulation of gonadotropin subunit genes in tilapia. Comp Biochem Physiol B Biochem Mol Biol (2001) 129(2-3):489-502. doi:10.1016/S1096-4959(01) 00345-1

116. Levy G, Jackson K, Degani G. Association between pituitary adenylate cyclaseactivating polypeptide and reproduction in the blue gourami. Gen Comp Endocrinol (2010) 166(1):83-93. doi:10.1016/j.ygcen.2009.09.015

117. Levy G, Degani G. Involvement of GnRH, PACAP and PRP in the reproduction of blue gourami females (Trichogaster trichopterus). J Mol Neurosci (2012) 48(3):603-16. doi:10.1007/s12031-012-9730-8

118. Matsuda K, Nakamura K, Shimakura S, Miura T, Kageyama H, Uchiyama $\mathrm{M}$, et al. Inhibitory effect of chicken gonadotropin-releasing hormone II on food intake in the goldfish, Carassius auratus. Horm Behav (2008) 54(1):83-9. doi:10.1016/j.yhbeh.2008.01.011 
119. Nishiguchi R, Azuma M, Yokobori E, Uchiyama M, Matsuda K. Gonadotropinreleasing hormone 2 suppresses food intake in the zebrafish, Danio rerio. Front Endocrinol (2012) 3:122. doi:10.3389/fendo.2012.00122

120. Chang JP, Freedman GL, de Leeuw R. Use of a pituitary cell dispersion method and primary culture system for the studies of gonadotropin-releasing hormone action in the goldfish, Carassius auratus. II. Extracellular calcium dependence and dopaminergic inhibition of gonadotropin responses. Gen Comp Endocrinol (1990) 77(2):274-82. doi:10.1016/0016-6480(90)90311-9

121. Chartrel N, Dujardin C, Anouar Y, Leprince J, Decker A, Clerens S, et al. Identification of 26RFa, a hypothalamic neuropeptide of the RFamide peptide family with orexigenic activity. Proc Natl Acad Sci U S A (2003) 100(25):15247-52. doi:10.1073/pnas.2434676100

122. Liu Y, Zhang Y, Li S, Huang W, Liu X, Lu D, et al. Molecular cloning and functional characterization of the first non-mammalian 26RFa/QRFP orthologue in goldfish, Carassius auratus. Mol Cell Endocrinol (2009) 303(1-2):82-90. doi:10.1016/j.mce.2009.01.009

123. Volkoff H, Peter RE. Interactions between orexin A, NPY and galanin in the control of food intake of the goldfish, Carassius auratus. Regul Pept (2001) 101(1-3):59-72. doi:10.1016/S0167-0115(01)00261-0

124. Guijarro AI, Delgado MJ, Pinillos ML, López-Patiño MA, Alonso-Bedate M, De Pedro N. Galanin and $\beta$-endorphin as feeding regulators in cyprinids: effect of temperature. Aquac Res (1999) 30(7):483-9. doi:10.1046/j.1365-2109.1999. 00360.x

125. Merchenthaler I, Lopez FJ, Negro-Vilar A. Colocalization of galanin and luteinizing hormone-releasing hormone in a subset of preoptic hypothalamic neurons: anatomical and functional correlates. Proc Natl Acad Sci U S A (1990) 87(16):6326-30. doi:10.1073/pnas.87.16.6326

126. Matsuda K, Shimakura S, Maruyama K, Miura T, Uchiyama M, Kawauchi $\mathrm{H}$, et al. Central administration of melanin-concentrating hormone $(\mathrm{MCH})$ suppresses food intake, but not locomotor activity, in the goldfish, Carassius auratus. Neurosci Lett (2006) 399(3):259-63. doi:10.1016/j.neulet.2006.02.005

127. Cerda-Reverter JM, Canosa LF, Peter RE. Regulation of the hypothalamic melanin-concentrating hormone neurons by sex steroids in the goldfish: possible role in the modulation of luteinizing hormone secretion. Neuroendocrinology (2006) 84(6):364-77. doi:10.1159/000098334

128. Cerda-Reverter JM, Schioth HB, Peter RE. The central melanocortin system regulates food intake in goldfish. Regul Pept (2003) 115(2):101-13. doi:10.1016/S0167-0115(03)00144-7

129. Schjolden J, Schioth HB, Larhammar D, Winberg S, Larson ET. Melanocortin peptides affect the motivation to feed in rainbow trout (Oncorhynchus mykiss). Gen Comp Endocrinol (2009) 160(2):134-8. doi:10.1016/j.ygcen.2008.11.003

130. Roa J. Role of GnRH neurons and their neuronal afferents as key integrators between food intake regulatory signals and the control of reproduction. Int J Endocrinol (2013) 2013:518046. doi:10.1155/2013/518046

131. Volkoff H, Peter RE. Effects of CART peptides on food consumption, feeding and associated behaviors in the goldfish, Carassius auratus: actions on neuropeptide Y- and orexin A-induced feeding. Brain Res (2000) 887(1):125-33. doi:10.1016/S0006-8993(00)03001-8

132. Volkoff H, Peter RE. Characterization of two forms of cocaine- and amphetamine-regulated transcript (CART) peptide precursors in goldfish: molecular cloning and distribution, modulation of expression by nutritional status, and interactions with leptin. Endocrinology (2001) 142(12):5076-88. doi:10.1210/en.142.12.5076

133. Lebrethon MC, Vandersmissen E, Gerard A, Parent AS, Bourguignon JP. Cocaine and amphetamine-regulated-transcript peptide mediation of leptin stimulatory effect on the rat gonadotropin-releasing hormone pulse generator in vitro. J Neuroendocrinol (2000) 12(5):383-5. doi:10.1046/j.1365-2826.2000. 00497.x

134. Parent AS, Lebrethon MC, Gerard A, Vandersmissen E, Bourguignon JP. Leptin effects on pulsatile gonadotropin releasing hormone secretion from the adult rat hypothalamus and interaction with cocaine and amphetamine regulated transcript peptide and neuropeptide Y. Regul Pept (2000) 92(1-3):17-24. doi:10.1016/S0167-0115(00)00144-0

135. Himick BA, Peter RE. CCK/gastrin-like immunoreactivity in brain and gut, and CCK suppression of feeding in goldfish. Am J Physiol (1994) 267(3 Pt 2):R841-51.

136. Himick BA, Golosinski AA, Jonsson AC, Peter RE. CCK/gastrin-like immunoreactivity in the goldfish pituitary: regulation of pituitary hormone secretion by CCK-like peptides in vitro. Gen Comp Endocrinol (1993) 92(1):88-103. doi:10.1006/gcen.1993.1146

137. Gonzalez R, Kerbel B, Chun A, Unniappan S. Molecular, cellular and physiological evidences for the anorexigenic actions of nesfatin-1 in goldfish. PLoS One (2010) 5(12):e15201. doi:10.1371/journal.pone.0015201

138. Kerbel B, Unniappan S. Nesfatin-1 suppresses energy intake, co-localises ghrelin in the brain and gut, and alters ghrelin, cholecystokinin and orexin mRNA expression in goldfish. J Neuroendocrinol (2012) 24(2):366-77. doi:10.1111/j. 1365-2826.2011.02246.x

139. Gonzalez R, Shepperd E, Thiruppugazh V, Lohan S, Grey CL, Chang JP, et al. Nesfatin-1 regulates the hypothalamo-pituitary-ovarian axis of fish. Biol Reprod (2012) 87(4):84. doi:10.1095/biolreprod.112.099630

140. Volkoff H, Eykelbosh AJ, Peter RE. Role of leptin in the control of feeding of goldfish Carassius auratus: interactions with cholecystokinin, neuropeptide $\mathrm{Y}$ and orexin A, and modulation by fasting. Brain Res (2003) 972(1-2):90-109. doi:10.1016/S0006-8993(03)02507-1

141. Murashita K, Uji S, Yamamoto T, Ronnestad I, Kurokawa T. Production of recombinant leptin and its effects on food intake in rainbow trout (Oncorhynchus mykiss). Comp Biochem Physiol B Biochem Mol Biol (2008) 150(4):377-84. doi:10.1016/j.cbpb.2008.04.007

142. Peyon P, Zanuy S, Carrillo M. Action of leptin on in vitro luteinizing hormone release in the European sea bass (Dicentrarchus labrax). Biol Reprod (2001) 65(5):1573-8. doi:10.1095/biolreprod65.5.1573

143. Weil C, Le Bail PY, Sabin N, Le Gac F. In vitro action of leptin on FSH and LH production in rainbow trout (Onchorynchus mykiss) at different stages of the sexual cycle. Gen Comp Endocrinol (2003) 130(1):2-12. doi:10.1016/S00166480(02)00504-X

144. Unniappan S, Lin X, Cervini L, Rivier J, Kaiya H, Kangawa K, et al. Goldfish ghrelin: molecular characterization of the complementary deoxyribonucleic acid, partial gene structure and evidence for its stimulatory role in food intake. Endocrinology (2002) 143(10):4143-6. doi:10.1210/en.2002-220644

145. Matsuda K, Miura T, Kaiya H, Maruyama K, Shimakura S, Uchiyama M, et al. Regulation of food intake by acyl and des-acyl ghrelins in the goldfish. Peptides (2006) 27(9):2321-5. doi:10.1016/j.peptides.2006.03.028

146. Miura T, Maruyama K, Kaiya H, Miyazato M, Kangawa K, Uchiyama M, et al. Purification and properties of ghrelin from the intestine of the goldfish, Carassius auratus. Peptides (2009) 30(4):758-65. doi:10.1016/j.peptides.2008.12.016

147. Jonsson E, Kaiya H, Bjornsson BT. Ghrelin decreases food intake in juvenile rainbow trout (Oncorhynchus mykiss) through the central anorexigenic corticotropin-releasing factor system. Gen Comp Endocrinol (2010) 166(1):39-46. doi:10.1016/j.ygcen.2009.11.001

148. Unniappan S, Peter RE. In vitro and in vivo effects of ghrelin on luteinizing hormone and growth hormone release in goldfish. Am J Physiol Regul Integr Comp Physiol (2004) 286(6):R1093-101. doi:10.1152/ajpregu.00669.2003

149. Sokolowska-Mikolajczyk M, Socha M, Szczerbik P, Epler P. The effects of ghrelin on the in vitro spontaneous and sGnRH-A stimulated luteinizing hormone (LH) release from the pituitary cells of common carp (Cyprinus carpio L.). Comp Biochem Physiol A Mol Integr Physiol (2009) 153(4):386-90. doi:10.1016/j.cbpa.2009.03.012

150. Wong KK, Ng SY, Lee LT, Ng HK, Chow BK. Orexins and their receptors from fish to mammals: a comparative approach. Gen Comp Endocrinol (2011) 171(2):124-30. doi:10.1016/j.ygcen.2011.01.001

151. Sakurai T, Amemiya A, Ishii M, Matsuzaki I, Chemelli RM, Tanaka H, et al. Orexins and orexin receptors: a family of hypothalamic neuropeptides and $\mathrm{G}$ protein-coupled receptors that regulate feeding behavior. Cell (1998) 92(4):573-85. doi:10.1016/S0092-8674(02)09256-5

152. Nakamachi T, Matsuda K, Maruyama K, Miura T, Uchiyama M, Funahashi $\mathrm{H}$, et al. Regulation by orexin of feeding behaviour and locomotor activity in the goldfish. J Neuroendocrinol (2006) 18(4):290-7. doi:10.1111/j.1365-2826. 2006.01415.x

153. Sasson R, Dearth RK, White RS, Chappell PE, Mellon PL. Orexin A induces GnRH gene expression and secretion from GT1-7 hypothalamic GnRH neurons. Neuroendocrinology (2006) 84(6):353-63. doi:10.1159/000098333

154. Russell SH, Small CJ, Kennedy AR, Stanley SA, Seth A, Murphy KG, et al. Orexin A interactions in the hypothalamo-pituitary gonadal axis. Endocrinology (2001) 142(12):5294-302. doi:10.1210/endo.142.12.8558

155. Campbell RE, Grove KL, Smith MS. Gonadotropin-releasing hormone neurons coexpress orexin 1 receptor immunoreactivity and receive direct contacts 
by orexin fibers. Endocrinology (2003) 144(4):1542-8. doi:10.1210/en.2002220958

156. Amiya N, Amano M, Oka Y, Iigo M, Takahashi A, Yamamori K. Immunohistochemical localization of orexin/hypocretin-like immunoreactive peptides and melanin-concentrating hormone in the brain and pituitary of medaka. Neurosci Lett (2007) 427(1):16-21. doi:10.1016/j.neulet.2007.07.043

157. Suzuki H, Miyoshi Y, Yamamoto T. Orexin-A (hypocretin 1)-like immunoreactivity in growth hormone-containing cells of the Japanese seaperch (Lateolabrax japonicus) pituitary. Gen Comp Endocrinol (2007) 150(2):205-11. doi:10.1016/j.ygcen.2006.08.008

158. Suzuki H, Matsumoto A, Yamamoto T. Orexin-B-like immunoreactivity localized in both luteinizing hormone- and thyroid-stimulating hormonecontaining cells in the Nile tilapia (Oreochromis niloticus) pituitary. Tissue Cell (2009) 41 (1):75-8. doi:10.1016/j.tice.2008.06.001

159. Tatemoto K, Carlquist M, Mutt V. Neuropeptide $Y$ - a novel brain peptide with structural similarities to peptide YY and pancreatic polypeptide. Nature (1982) 296(5858):659-60. doi:10.1038/296659a0

160. Valassi E, Scacchi M, Cavagnini F. Neuroendocrine control of food intake. Nutr Metab Cardiovasc Dis (2008) 18(2):158-68. doi:10.1016/j.numecd.2007.06.004

161. de Pedro N, Lopez-Patino MA, Guijarro AI, Pinillos ML, Delgado MJ, AlonsoBedate M. NPY receptors and opioidergic system are involved in NPY-induced feeding in goldfish. Peptides (2000) 21(10):1495-502. doi:10.1016/S01969781(00)00303-X

162. Narnaware YK, Peyon PP, Lin X, Peter RE. Regulation of food intake by neuropeptide Y in goldfish. Am J Physiol Regul Integr Comp Physiol (2000) 279(3):R1025-34.

163. Narnaware YK, Peter RE. Effects of food deprivation and refeeding on neuropeptide Y (NPY) mRNA levels in goldfish. Comp Biochem Physiol B Biochem Mol Biol (2001) 129(2-3):633-7. doi:10.1016/S1096-4959(01)00359-1

164. Narnaware YK, Peter RE. Neuropeptide Y stimulates food consumption through multiple receptors in goldfish. Physiol Behav (2001) 74(1-2):185-90. doi:10.1016/S0031-9384(01)00556-X

165. Kamijo M, Kojima K, Maruyama K, Konno N, Motohashi E, Ikegami T, et al. Neuropeptide $\mathrm{Y}$ in tiger puffer (Takifugu rubripes): distribution, cloning, characterization, and mRNA expression responses to prandial condition. Zoolog Sci (2011) 28(12):882-90. doi:10.2108/zsj.28.882

166. Wojcik-Gladysz A, Polkowska J. Neuropeptide Y - a neuromodulatory link between nutrition and reproduction at the central nervous system level. Reprod Biol (2006) 6(Suppl 2):21-8.

167. Breton B, Motin A, Billard R, Kah O, Geoffre S, Precigoux G. Immunoreactive gonadotropin-releasing hormone-like material in the brain and the pituitary gland during the periovulatory period in the brown trout (Salmo trutta L.): relationships with the plasma and pituitary gonadotropin. Gen Comp Endocrinol (1986) 61(1):109-19. doi:10.1016/0016-6480(86)90255-8

168. Danger JM, Breton B, Vallarino M, Fournier A, Pelletier G, Vaudry H. Neuropeptide-Y in the trout brain and pituitary: localization, characterization, and action on gonadotropin release. Endocrinology (1991) 128(5):2360-8. doi:10.1210/endo-128-5-2360

169. Chiba A, Sohn YC, Honma Y. Distribution of neuropeptide Y and gonadotropin-releasing hormone immunoreactivities in the brain and hypophysis of the ayu, Plecoglossus altivelis (Teleostei). Arch Histol Cytol (1996) 59(2):137-48. doi:10.1679/aohc.59.137

170. Amiya N, Amano M, Tabuchi A, Oka Y. Anatomical relations between neuropeptide $\mathrm{Y}$, galanin, and gonadotropin-releasing hormone in the brain of chondrostean, the Siberian sturgeon Acipenser baeri. Neurosci Lett (2011) 503(2):87-92. doi:10.1016/j.neulet.2011.08.008

171. Gaikwad A, Biju KC, Subhedar N. GnRH-LH secreting cells axis in the pituitary of the teleost Clarias batrachus responds to neuropeptide Y treatment: an immunocytochemical study. Gen Comp Endocrinol (2003) 131(2):126-33. doi:10.1016/S0016-6480(02)00631-7

172. Ukena K, Tachibana T, Iwakoshi-Ukena E, Saito Y, Minakata H, Kawaguchi $\mathrm{R}$, et al. Identification, localization, and function of a novel avian hypothalamic neuropeptide, $26 \mathrm{RFa}$, and its cognate receptor, $G$ protein-coupled receptor103. Endocrinology (2010) 151(5):2255-64. doi:10.1210/en.2009-1478

173. Primeaux SD. QRFP in female rats: effects on high fat food intake and hypothalamic gene expression across the estrous cycle. Peptides (2011) 32(6):1270-5. doi:10.1016/j.peptides.2011.03.022
174. Takayasu S, Sakurai T, Iwasaki S, Teranishi H, Yamanaka A, Williams SC, et al. A neuropeptide ligand of the G protein-coupled receptor GPR103 regulates feeding, behavioral arousal, and blood pressure in mice. Proc Natl Acad Sci U S A (2006) 103(19):7438-43. doi:10.1073/pnas.0602371103

175. Navarro VM, Fernandez-Fernandez R, Nogueiras R, Vigo E, Tovar S, Chartrel $\mathrm{N}$, et al. Novel role of $26 \mathrm{RFa}$, a hypothalamic RFamide orexigenic peptide, as putative regulator of the gonadotropic axis. J Physiol (2006) 573(Pt 1):237-49. doi:10.1113/jphysiol.2006.106856

176. Gundlach AL. Galanin/GALP and galanin receptors: role in central control of feeding, body weight/obesity and reproduction? Eur J Pharmacol (2002) 440(2-3):255-68. doi:10.1016/S0014-2999(02)01433-4

177. Vrontakis ME. Galanin: a biologically active peptide. Curr Drug Targets CNS Neurol Disord (2002) 1(6):531-41. doi:10.2174/1568007023338914

178. Rajendren G, Li X. Galanin synaptic input to gonadotropin-releasing hormone perikarya in juvenile and adult female mice: implications for sexual maturity. Brain Res Dev Brain Res (2001) 131(1-2):161-5. doi:10.1016/S0165-3806(01) 00257-7

179. Merchenthaler I, Lopez FJ, Lennard DE, Negro-Vilar A. Sexual differences in the distribution of neurons coexpressing galanin and luteinizing hormonereleasing hormone in the rat brain. Endocrinology (1991) 129(4):1977-86. doi:10.1210/endo-129-4-1977

180. Dudas B, Merchenthaler I. Bi-directional associations between galanin and luteinizing hormone-releasing hormone neuronal systems in the human diencephalon. Neuroscience (2004) 127(3):695-707. doi:10.1016/j.neuroscience. 2004.05.018

181. Mitchell V, Bouret S, Prevot V, Jennes L, Beauvillain JC. Evidence for expression of galanin receptor Gal-R1 mRNA in certain gonadotropin releasing hormone neurones of the rostral preoptic area. J Neuroendocrinol (1999) 11(10):805-12. doi:10.1046/j.1365-2826.1999.00399.x

182. Batten TF, Moons L, Cambre M, Vandesande F. Anatomical distribution of galanin-like immunoreactivity in the brain and pituitary of teleost fishes. Neurosci Lett (1990) 111(1-2):12-7. doi:10.1016/0304-3940(90)90336-8

183. Anglade I, Wang Y, Jensen J, Tramu G, Kah O, Conlon JM. Characterization of trout galanin and its distribution in trout brain and pituitary. J Comp Neurol (1994) 350(1):63-74. doi:10.1002/cne.903500105

184. Power DM, Canario AV, Ingleton PM. Somatotropin release-inhibiting factor and galanin innervation in the hypothalamus and pituitary of seabream (Sparus aurata). Gen Comp Endocrinol (1996) 101(3):264-74. doi:10.1006/gcen.1996. 0029

185. Rodriguez-Gomez FJ, Rendon-Unceta MC, Sarasquete C, Munoz-Cueto JA. Localization of galanin-like immunoreactive structures in the brain of the Senegalese sole, Solea senegalensis. Histochem J (2000) 32(2):123-31. doi:10. 1023/A:1004074430973

186. Kauffman AS, Rissman EF. The evolutionarily conserved gonadotropinreleasing hormone II modifies food intake. Endocrinology (2004) 145(2):686-91. doi:10.1210/en.2003-1150

187. Kauffman AS, Wills A, Millar RP, Rissman EF. Evidence that the type-2 gonadotrophin-releasing hormone $(\mathrm{GnRH})$ receptor mediates the behavioural effects of GnRH-II on feeding and reproduction in musk shrews. J Neuroendocrinol (2005) 17(8):489-97. doi:10.1111/j.1365-2826.2005.01334.x

188. Volkoff H, Peter RE. Actions of two forms of gonadotropin releasing hormone and a GnRH antagonist on spawning behavior of the goldfish Carassius auratus. Gen Comp Endocrinol (1999) 116(3):347-55. doi:10.1006/gcen. 1999.7377

189. Canosa LF, Stacey N, Peter RE. Changes in brain mRNA levels of gonadotropinreleasing hormone, pituitary adenylate cyclase activating polypeptide, and somatostatin during ovulatory luteinizing hormone and growth hormone surges in goldfish. Am J Physiol Regul Integr Comp Physiol (2008) 295(6):R1815-21. doi:10.1152/ajpregu.00166.2008

190. Kim MH, Oka Y, Amano M, Kobayashi M, Okuzawa K, Hasegawa Y, et al. Immunocytochemical localization of sGnRH and cGnRH-II in the brain of goldfish, Carassius auratus. J Comp Neurol (1995) 356(1):72-82. doi:10.1002/ cne. 903560105

191. Shahjahan M, Hamabata T, Motohashi E, Doi H, Ando H. Differential expression of three types of gonadotropin-releasing hormone genes during the spawning season in grass puffer, Takifugu niphobles. Gen Comp Endocrinol (2010) 167(1):153-63. doi:10.1016/j.ygcen.2010.01.018 
192. Miyata A, Arimura A, Dahl RR, Minamino N, Uehara A, Jiang L, et al. Isolation of a novel 38 residue-hypothalamic polypeptide which stimulates adenylate cyclase in pituitary cells. Biochem Biophys Res Commun (1989) 164(1):567-74. doi:10.1016/0006-291X(89)91757-9

193. Morley JE, Horowitz M, Morley PM, Flood JF. Pituitary adenylate cyclase activating polypeptide (PACAP) reduces food intake in mice. Peptides (1992) 13(6):1133-5. doi:10.1016/0196-9781(92)90019-Y

194. Tachibana T, Saito S, Tomonaga S, Takagi T, Saito ES, Boswell T, et al. Intracerebroventricular injection of vasoactive intestinal peptide and pituitary adenylate cyclase-activating polypeptide inhibits feeding in chicks. Neurosci Lett (2003) 339(3):203-6. doi:10.1016/S0304-3940(03)00017-X

195. Tachibana T, Tomonaga S, Oikawa D, Saito S, Takagi T, Saito ES, et al. Pituitary adenylate cyclase activating polypeptide and vasoactive intestinal peptide inhibit feeding in the chick brain by different mechanisms. Neurosci Lett (2003) 348(1):25-8. doi:10.1016/S0304-3940(03)00646-3

196. Matsuda K, Kang KS, Sakashita A, Yahashi S, Vaudry H. Behavioral effect of neuropeptides related to feeding regulation in fish. Ann N Y Acad Sci (2011) 1220:117-26. doi:10.1111/j.1749-6632.2010.05884.x

197. Wong AO, Li WS, Lee EK, Leung MY, Tse LY, Chow BK, et al. Pituitary adenylate cyclase activating polypeptide as a novel hypophysiotropic factor in fish. Biochem Cell Biol (2000) 78(3):329-43. doi:10.1139/o00-055

198. Wong AO, Leung MY, Shea WL, Tse LY, Chang JP, Chow BK. Hypophysiotropic action of pituitary adenylate cyclase-activating polypeptide (PACAP) in the goldfish: immunohistochemical demonstration of PACAP in the pituitary, PACAP stimulation of growth hormone release from pituitary cells, and molecular cloning of pituitary type I PACAP receptor. Endocrinology (1998) 139(8):3465-79. doi:10.1210/endo.139.8.6145

199. Montero M, Yon L, Rousseau K, Arimura A, Fournier A, Dufour S, et al. Distribution, characterization, and growth hormone-releasing activity of pituitary adenylate cyclase-activating polypeptide in the European eel, Anguilla anguilla. Endocrinology (1998) 139(10):4300-10. doi:10.1210/endo. 139.10.6239

200. Kawauchi H, Kawazoe I, Tsubokawa M, Kishida M, Baker BI. Characterization of melanin-concentrating hormone in chum salmon pituitaries. Nature (1983) 305(5932):321-3. doi:10.1038/305321a0

201. Takahashi A, Tsuchiya K, Yamanome T, Amano M, Yasuda A, Yamamori $\mathrm{K}$, et al. Possible involvement of melanin-concentrating hormone in food intake in a teleost fish, barfin flounder. Peptides (2004) 25(10):1613-22. doi:10.1016/j.peptides.2004.02.022

202. Tuziak SM, Volkoff H. A preliminary investigation of the role of melaninconcentrating hormone $(\mathrm{MCH})$ and its receptors in appetite regulation of winter flounder (Pseudopleuronectes americanus). Mol Cell Endocrinol (2012) 348(1):281-96. doi:10.1016/j.mce.2011.09.015

203. Qu D, Ludwig DS, Gammeltoft S, Piper M, Pelleymounter MA, Cullen MJ, et al. A role for melanin-concentrating hormone in the central regulation of feeding behaviour. Nature (1996) 380(6571):243-7. doi:10.1038/380243a0

204. Pissios P, Bradley RL, Maratos-Flier E. Expanding the scales: the multiple roles of $\mathrm{MCH}$ in regulating energy balance and other biological functions. Endocr $\operatorname{Rev}(2006)$ 27(6):606-20. doi:10.1210/er.2006-0021

205. Matsuda K, Kojima K, Shimakura S, Takahashi A. Regulation of food intake by melanin-concentrating hormone in goldfish. Peptides (2009) 30(11):2060-5. doi:10.1016/j.peptides.2009.02.015

206. Shimakura S, Kojima K, Nakamachi T, Kageyama H, Uchiyama M, Shioda $\mathrm{S}$, et al. Neuronal interaction between melanin-concentrating hormone- and alpha-melanocyte-stimulating hormone-containing neurons in the goldfish hypothalamus. Peptides (2008) 29(8):1432-40. doi:10.1016/j. peptides.2008.04.009

207. Naufahu J, Cunliffe AD, Murray JF. The roles of melanin-concentrating hormone in energy balance and reproductive function: are they connected? Reproduction (2013) 146(5):R141-50. doi:10.1530/REP-12-0385

208. Smith MS, Grove KL. Integration of the regulation of reproductive function and energy balance: lactation as a model. Front Neuroendocrinol (2002) 23(3):225-56. doi:10.1016/S0091-3022(02)00002-X

209. Williamson-Hughes PS, Grove KL, Smith MS. Melanin concentrating hormone (MCH): a novel neural pathway for regulation of GnRH neurons. Brain Res (2005) 1041(2):117-24. doi:10.1016/j.brainres.2004.11.066

210. Chiocchio SR, Gallardo MG, Louzan P, Gutnisky V, Tramezzani JH. Melaninconcentrating hormone stimulates the release of luteinizing hormone-releasing hormone and gonadotropins in the female rat acting at both median eminence and pituitary levels. Biol Reprod (2001) 64(5):1466-72. doi:10.1095/ biolreprod64.5.1466

211. Schauer E, Trautinger F, Kock A, Schwarz A, Bhardwaj R, Simon M, et al. Proopiomelanocortin-derived peptides are synthesized and released by human keratinocytes. J Clin Invest (1994) 93(5):2258-62. doi:10.1172/JCI117224

212. Cerda-Reverter JM, Ringholm A, Schioth HB, Peter RE. Molecular cloning, pharmacological characterization, and brain mapping of the melanocortin 4 receptor in the goldfish: involvement in the control of food intake. Endocrinology (2003) 144(6):2336-49. doi:10.1210/en.2002-0213

213. Salbert G, Chauveau I, Bonnec G, Valotaire Y, Jego P. One of the two trout proopiomelanocortin messenger RNAs potentially encodes new peptides. $\mathrm{Mol}$ Endocrinol (1992) 6(10):1605-13. doi:10.1210/mend.6.10.1448114

214. Kuhar MJ, Adams S, Dominguez G, Jaworski J, Balkan B. CART peptides. Neuropeptides (2002) 36(1):1-8. doi:10.1054/npep.2002.0887

215. Sakata I, Nakamura K, Yamazaki M, Matsubara M, Hayashi Y, Kangawa $\mathrm{K}$, et al. Ghrelin-producing cells exist as two types of cells, closed- and opened-type cells, in the rat gastrointestinal tract. Peptides (2002) 23(3):531-6. doi:10.1016/S0196-9781(01)00633-7

216. Kehoe AS, Volkoff H. Cloning and characterization of neuropeptide Y (NPY) and cocaine and amphetamine regulated transcript (CART) in Atlantic cod (Gadus morhua). Comp Biochem Physiol A Mol Integr Physiol (2007) 146(3):451-61. doi:10.1016/j.cbpa.2006.12.026

217. Kobayashi Y, Peterson BC, Waldbieser GC. Association of cocaine- and amphetamine-regulated transcript (CART) messenger RNA level, food intake, and growth in channel catfish. Comp Biochem Physiol A Mol Integr Physiol (2008) 151(2):219-25. doi:10.1016/j.cbpa.2008.06.029

218. Nishio S, Gibert Y, Berekelya L, Bernard L, Brunet F, Guillot E, et al. Fasting induces CART down-regulation in the zebrafish nervous system in a cannabinoid receptor 1-dependent manner. Mol Endocrinol (2012) 26(8):1316-26. doi:10.1210/me.2011-1180

219. Murashita K, Kurokawa T, Ebbesson LO, Stefansson SO, Ronnestad I. Characterization, tissue distribution, and regulation of agouti-related protein (AgRP), cocaine- and amphetamine-regulated transcript (CART) and neuropeptide Y (NPY) in Atlantic salmon (Salmo salar). Gen Comp Endocrinol (2009) 162(2):160-71. doi:10.1016/j.ygcen.2009.03.015

220. Leslie RA, Sanders SJ, Anderson SI, Schuhler S, Horan TL, Ebling FJ. Appositions between cocaine and amphetamine-related transcript- and gonadotropin releasing hormone-immunoreactive neurons in the hypothalamus of the Siberian hamster. Neurosci Lett (2001) 314(3):111-4. doi:10.1016/S0304-3940(01) 02291-1

221. Singru PS, Mazumdar M, Sakharkar AJ, Lechan RM, Thim L, Clausen JT, et al. Immunohistochemical localization of cocaine- and amphetamine-regulated transcript peptide in the brain of the catfish, Clarias batrachus (Linn.). J Comp Neurol (2007) 502(2):215-35. doi:10.1002/cne.21295

222. Barsagade VG, Mazumdar M, Singru PS, Thim L, Clausen JT, Subhedar N. Reproductive phase-related variations in cocaine- and amphetamine-regulated transcript (CART) in the olfactory system, forebrain, and pituitary of the female catfish, Clarias batrachus (Linn.). J Comp Neurol (2010) 518(13):2503-24. doi:10.1002/cne.22349

223. Kuriyama G, Takekoshi S, Tojo K, Nakai Y, Kuhar MJ, Osamura RY. Cocaine- and amphetamine-regulated transcript peptide in the rat anterior pituitary gland is localized in gonadotrophs and suppresses prolactin secretion. Endocrinology (2004) 145(5):2542-50. doi:10.1210/en.2003-0845

224. Moran TH, Kinzig KP. Gastrointestinal satiety signals II. Cholecystokinin. Am J Physiol Gastrointest Liver Physiol (2004) 286(2):G183-8. doi:10.1152/ajpgi. 00434.2003

225. Ichimaru T, Matsuyama S, Ohkura S, Mori Y, Okamura H. Central cholecystokinin-octapeptide accelerates the activity of the hypothalamic gonadotropin-releasing hormone pulse generator in goats. J Neuroendocrinol (2003) 15(1):80-6. doi:10.1046/j.1365-2826.2003.00965.x

226. Kimura F, Hashimoto R, Kawakami M. The stimulatory effect of cholecystokinin implanted in the medial preoptic area on luteinizing hormone secretion in the ovariectomized estrogen-primed rat. Endocrinol Jpn (1983) 30(3):305-9. doi:10.1507/endocri1954.30.305

227. Oh IS, Shimizu H, Satoh T, Okada S, Adachi S, Inoue K, et al. Identification of nesfatin-1 as a satiety molecule in the hypothalamus. Nature (2006) 443(7112):709-12. doi:10.1038/nature05162 
228. Garcia-Galiano D, Navarro VM, Roa J, Ruiz-Pino F, Sanchez-Garrido MA, Pineda R, et al. The anorexigenic neuropeptide, nesfatin-1, is indispensable for normal puberty onset in the female rat. J Neurosci (2010) 30(23):7783-92. doi:10.1523/JNEUROSCI.5828-09.2010

229. Zhang Y, Proenca R, Maffei M, Barone M, Leopold L, Friedman JM. Positional cloning of the mouse obese gene and its human homologue. Nature (1994) 372(6505):425-32. doi:10.1038/372425a0

230. Crown A, Clifton DK, Steiner RA. Neuropeptide signaling in the integration of metabolism and reproduction. Neuroendocrinology (2007) 86(3):175-82. doi:10.1159/000109095

231. de Pedro N, Martinez-Alvarez R, Delgado MJ. Acute and chronic leptin reduces food intake and body weight in goldfish (Carassius auratus). J Endocrinol (2006) 188(3):513-20. doi:10.1677/joe.1.06349

232. Aguilar AJ, Conde-Sieira M, Polakof S, Miguez JM, Soengas JL. Central leptin treatment modulates brain glucosensing function and peripheral energy metabolism of rainbow trout. Peptides (2010) 31(6):1044-54. doi:10.1016/j. peptides.2010.02.026

233. Maffei M, Halaas J, Ravussin E, Pratley RE, Lee GH, Zhang Y, et al. Leptin levels in human and rodent: measurement of plasma leptin and ob RNA in obese and weight-reduced subjects. Nat Med (1995) 1(11):1155-61. doi:10.1038/nm1195-1155

234. Watanobe H. Leptin directly acts within the hypothalamus to stimulate gonadotropin-releasing hormone secretion in vivo in rats. J Physiol (2002) 545(Pt 1):255-68. doi:10.1113/jphysiol.2002.023895

235. Smith GD, Jackson LM, Foster DL. Leptin regulation of reproductive function and fertility. Theriogenology (2002) 57(1):73-86. doi:10.1016/S0093-691X(01) 00658-6

236. Barb CR, Hausman GJ, Czaja K. Leptin: a metabolic signal affecting central regulation of reproduction in the pig. Domest Anim Endocrinol (2005) 29(1):186-92. doi:10.1016/j.domaniend.2005.02.024

237. Froiland E, Murashita K, Jorgensen EH, Kurokawa T. Leptin and ghrelin in anadromous arctic charr: cloning and change in expressions during a seasonal feeding cycle. Gen Comp Endocrinol (2010) 165(1):136-43. doi:10.1016/j.ygcen.2009.06.010

238. Trombley S, Schmitz M. Leptin in fish: possible role in sexual maturation in male Atlantic salmon. Fish Physiol Biochem (2013) 39(1):103-6. doi:10.1007/s10695-012-9731-0

239. Kaiya H, Kojima M, Hosoda H, Riley LG, Hirano T, Grau EG, et al. Amidated fish ghrelin: purification, cDNA cloning in the Japanese eel and its biological activity. J Endocrinol (2003) 176(3):415-23. doi:10.1677/joe.0.1760415

240. Kaiya H, Kojima M, Hosoda H, Moriyama S, Takahashi A, Kawauchi H, et al. Peptide purification, complementary deoxyribonucleic acid (DNA) and genomic DNA cloning, and functional characterization of ghrelin in rainbow trout. Endocrinology (2003) 144(12):5215-26. doi:10.1210/en.2003-1085

241. Kaiya H, Miyazato M, Kangawa K, Peter RE, Unniappan S. Ghrelin: a multifunctional hormone in non-mammalian vertebrates. Comp Biochem Physiol A Mol Integr Physiol (2008) 149(2):109-28. doi:10.1016/j.cbpa.2007.12.004

242. Kang KS, Yahashi S, Matsuda K. Central and peripheral effects of ghrelin on energy balance, food intake and lipid metabolism in teleost fish. Peptides (2011) 32(11):2242-7. doi:10.1016/j.peptides.2011.05.006

243. Terova G, Rimoldi S, Bernardini G, Gornati R, Saroglia M. Sea bass ghrelin: molecular cloning and mRNA quantification during fasting and refeeding. Gen Comp Endocrinol (2008) 155(2):341-51. doi:10.1016/j.ygcen.2007.05.028

244. Amole N, Unniappan S. Fasting induces preproghrelin mRNA expression in the brain and gut of zebrafish, Danio rerio. Gen Comp Endocrinol (2009) 161(1):133-7. doi:10.1016/j.ygcen.2008.11.002

245. Jonsson E, Forsman A, Einarsdottir IE, Kaiya H, Ruohonen K, Bjornsson BT. Plasma ghrelin levels in rainbow trout in response to fasting, feeding and food composition, and effects of ghrelin on voluntary food intake. Comp Biochem Physiol A Mol Integr Physiol (2007) 147(4):1116-24. doi:10.1016/j.cbpa.2007. 03.024

246. Nieminen P, Mustonen AM, Hyvarinen H. Fasting reduces plasma leptinand ghrelin-immunoreactive peptide concentrations of the burbot (Lota lota) at 2 degrees C but not at 10 degrees C. Zoolog Sci (2003) 20(9):1109-15. doi:10.2108/zsj.20.1109

247. Jonsson E. The role of ghrelin in energy balance regulation in fish. Gen Comp Endocrinol (2013) 187:79-85. doi:10.1016/j.ygcen.2013.03.013
248. Tena-Sempere M. Ghrelin as a pleotrophic modulator of gonadal function and reproduction. Nat Clin Pract Endocrinol Metab (2008) 4(12):666-74. doi:10.1038/ncpendmet1003

249. Chan $\mathrm{CB}$, Cheng $\mathrm{CH}$. Identification and functional characterization of two alternatively spliced growth hormone secretagogue receptor transcripts from the pituitary of black seabream Acanthopagrus schlegeli. Mol Cell Endocrinol (2004) 214(1-2):81-95. doi:10.1016/j.mce.2003.11.020

250. Grey CL, Grayfer L, Belosevic M, Chang JP. Ghrelin stimulation of gonadotropin (LH) release from goldfish pituitary cells: presence of the growth hormone secretagogue receptor (GHS-Rla) and involvement of voltagesensitive Ca2+ channels. Mol Cell Endocrinol (2010) 317(1-2):64-77. doi:10. 1016/j.mce.2009.12.024

251. Schneider JE, Wise JD, Benton NA, Brozek JM, Keen-Rhinehart E. When do we eat? Ingestive behavior, survival, and reproductive success. Horm Behav (2013) 64(4):702-28. doi:10.1016/j.yhbeh.2013.07.005

252. Milla S, Wang N, Mandiki SN, Kestemont P. Corticosteroids: friends or foes of teleost fish reproduction? Comp Biochem Physiol A Mol Integr Physiol (2009) 153(3):242-51. doi:10.1016/j.cbpa.2009.02.027

253. Castellano JM, Bentsen AH, Mikkelsen JD, Tena-Sempere M. Kisspeptins: bridging energy homeostasis and reproduction. Brain Res (2010) 1364:129-38. doi:10.1016/j.brainres.2010.08.057

254. Smith JT, Acohido BV, Clifton DK, Steiner RA. KiSS-1 neurones are direct targets for leptin in the ob/ob mouse. J Neuroendocrinol (2006) 18(4):298-303. doi:10.1111/j.1365-2826.2006.01417.x

255. Backholer K, Smith JT, Rao A, Pereira A, Iqbal J, Ogawa S, et al. Kisspeptin cells in the ewe brain respond to leptin and communicate with neuropeptide Y and proopiomelanocortin cells. Endocrinology (2010) 151(5):2233-43. doi:10.1210/en.2009-1190

256. Fu LY, van den Pol AN. Kisspeptin directly excites anorexigenic proopiomelanocortin neurons but inhibits orexigenic neuropeptide $Y$ cells by an indirect synaptic mechanism. J Neurosci (2010) 30(30):10205-19. doi:10.1523/ JNEUROSCI.2098-10.2010

257. Mechaly AS, Vinas J, Piferrer F. Gene structure analysis of kisspeptin-2 (Kiss2) in the Senegalese sole (Solea senegalensis): characterization of two splice variants of Kiss2, and novel evidence for metabolic regulation of kisspeptin signaling in non-mammalian species. Mol Cell Endocrinol (2011) 339(1-2):14-24. doi:10.1016/j.mce.2011.03.004

258. Tachibana T, Sato M, Takahashi H, Ukena K, Tsutsui K, Furuse $M$. Gonadotropin-inhibiting hormone stimulates feeding behavior in chicks. Brain Res (2005) 1050(1-2):94-100. doi:10.1016/j.brainres.2005.05.035

259. Johnson MA, Tsutsui K, Fraley GS. Rat RFamide-related peptide-3 stimulates GH secretion, inhibits LH secretion, and has variable effects on sex behavior in the adult male rat. Horm Behav (2007) 51(1):171-80. doi:10.1016/j.yhbeh. 2006.09.009

260. Murakami M, Matsuzaki T, Iwasa T, Yasui T, Irahara M, Osugi T, et al. Hypophysiotropic role of RFamide-related peptide-3 in the inhibition of LH secretion in female rats. J Endocrinol (2008) 199(1):105-12. doi:10.1677/JOE08-0197

261. Qi Y, Oldfield BJ, Clarke IJ. Projections of RFamide-related peptide-3 neurones in the ovine hypothalamus, with special reference to regions regulating energy balance and reproduction. J Neuroendocrinol (2009) 21(8):690-7. doi:10.1111/j.1365-2826.2009.01886.x

262. Ahima RS, Saper CB, Flier JS, Elmquist JK. Leptin regulation of neuroendocrine systems. Front Neuroendocrinol (2000) 21(3):263-307. doi:10.1006/frne.2000. 0197

263. Williams G, Bing C, Cai XJ, Harrold JA, King PJ, Liu XH. The hypothalamus and the control of energy homeostasis: different circuits, different purposes. Physiol Behav (2001) 74(4-5):683-701. doi:10.1016/S0031-9384(01) 00612-6

264. Li GG, Liang XF, Xie Q, Li G, Yu Y, Lai K. Gene structure, recombinant expression and functional characterization of grass carp leptin. Gen Comp Endocrinol (2010) 166(1):117-27. doi:10.1016/j.ygcen.2009.10.009

265. Aguilar AJ, Conde-Sieira M, Lopez-Patino MA, Miguez JM, Soengas JL. In vitro leptin treatment of rainbow trout hypothalamus and hindbrain affects glucosensing and gene expression of neuropeptides involved in food intake regulation. Peptides (2011) 32(2):232-40. doi:10.1016/j.peptides.2010. 11.007 
266. Chisada S-I, Kurokawa T, Murashita K, Rønnestad I, Taniguchi Y, Toyoda A, et al. Leptin receptor-deficient (knockout) medaka, Oryzias latipes, show chronical up-regulated levels of orexigenic neuropeptides, elevated food intake and stage specific effects on growth and fat allocation. Gen Comp Endocrinol (2014) 195:9-20. doi:10.1016/j.ygcen.2013.10.008

267. Matsuda K, Kojima K, Shimakura S, Wada K, Maruyama K, Uchiyama $\mathrm{M}$, et al. Corticotropin-releasing hormone mediates alpha-melanocytestimulating hormone-induced anorexigenic action in goldfish. Peptides (2008) 29(11):1930-6. doi:10.1016/j.peptides.2008.06.028

268. Shimakura S, Miura T, Maruyama K, Nakamachi T, Uchiyama M, Kageyama $\mathrm{H}$, et al. Alpha-melanocyte-stimulating hormone mediates melanin-concentrating hormone-induced anorexigenic action in goldfish. Horm Behav (2008) 53(2):323-8. doi:10.1016/j.yhbeh.2007.10.009

269. Kang KS, Shimizu K, Azuma M, Ui Y, Nakamura K, Uchiyama M, et al. Gonadotropin-releasing hormone II (GnRH II) mediates the anorexigenic actions of alpha-melanocyte-stimulating hormone (alpha-MSH) and corticotropin-releasing hormone (CRH) in goldfish. Peptides (2011) 32(1):31-5. doi:10.1016/j.peptides.2010.10.013

270. Kojima K, Kamijo M, Kageyama H, Uchiyama M, Shioda S, Matsuda K. Neuronal relationship between orexin-A- and neuropeptide Y-induced orexigenic actions in goldfish. Neuropeptides (2009) 43(2):63-71. doi:10.1016/j.npep. 2009.01.004

271. Kojima K, Amiya N, Kamijo M, Kageyama H, Uchiyama M, Shioda S, et al. Relationship between alpha-melanocyte-stimulating hormone- and neuropeptide Y-containing neurons in the goldfish hypothalamus. Gen Comp Endocrinol (2010) 167(3):366-72. doi:10.1016/j.ygcen.2009.12.004

272. Matsuda K, Kojima K, Shimakura S, Miura T, Uchiyama M, Shioda S, et al. Relationship between melanin-concentrating hormone- and neuropeptide Ycontaining neurons in the goldfish hypothalamus. Comp Biochem Physiol A Mol Integr Physiol (2009) 153(1):3-7. doi:10.1016/j.cbpa.2008.10.002

273. Miura T, Maruyama K, Shimakura S, Kaiya H, Uchiyama M, Kangawa $\mathrm{K}$, et al. Regulation of food intake in the goldfish by interaction between ghrelin and orexin. Peptides (2007) 28(6):1207-13. doi:10.1016/j.peptides. 2007.03.023

274. Miura T, Maruyama K, Shimakura S, Kaiya H, Uchiyama M, Kangawa K, et al. Neuropeptide Y mediates ghrelin-induced feeding in the goldfish, Carassius auratus. Neurosci Lett (2006) 407(3):279-83. doi:10.1016/j.neulet.2006.08.071

275. Amano M, Amiya N, Hiramatsu M, Tomioka T, Oka Y. Interaction between neuropeptide $\mathrm{Y}$ immunoreactive neurons and galanin immunoreactive neurons in the brain of the masu salmon, Oncorhynchus masou. Neurosci Lett (2009) 462(1):33-8. doi:10.1016/j.neulet.2009.06.067

276. Peng C, Trudeau VL, Peter RE. Seasonal variation of neuropeptide Y actions on growth hormone and gonadotropin-II secretion in the goldfish: effects of sex steroids. J Neuroendocrinol (1993) 5(3):273-80. doi:10.1111/j.1365-2826. 1993.tb00483.x

277. Flores A, Maldonado R, Berrendero F. Cannabinoid-hypocretin cross-talk in the central nervous system: what we know so far. Front Neurosci (2013) 7:256. doi:10.3389/fnins.2013.00256

278. Bermudez-Silva FJ, Cardinal P, Cota D. The role of the endocannabinoid system in the neuroendocrine regulation of energy balance. J Psychopharmacol (2012) 26(1):114-24. doi:10.1177/0269881111408458

279. Piccinetti CC, Migliarini B, Petrosino S, Di Marzo V, Carnevali O. Anandamide and AM251, via water, modulate food intake at central and peripheral level in fish. Gen Comp Endocrinol (2010) 166(2):259-67. doi:10.1016/j.ygcen.2009. 09.017

280. Valenti M, Cottone E, Martinez R, De Pedro N, Rubio M, Viveros MP, et al. The endocannabinoid system in the brain of Carassius auratus and its possible role in the control of food intake. J Neurochem (2005) 95(3):662-72. doi:10.1111/j.1471-4159.2005.03406.x

281. Cottone E, Pomatto V, Bovolin P. Role of the endocannabinoid system in the central regulation of nonmammalian vertebrate reproduction. Int J Endocrinol (2013) 2013:941237. doi:10.1155/2013/941237

282. Battista N, Meccariello R, Cobellis G, Fasano S, Di Tommaso M, Pirazzi V, et al. The role of endocannabinoids in gonadal function and fertility along the evolutionary axis. Mol Cell Endocrinol (2012) 355(1):1-14. doi:10.1016/j.mce. 2012.01.014

283. Volff JN. Genome evolution and biodiversity in teleost fish. Heredity (2004) 94(3):280-94. doi:10.1038/sj.hdy.6800635

Conflict of Interest Statement: The authors declare that the research was conducted in the absence of any commercial or financial relationships that could be construed as a potential conflict of interest.

Received: 10 February 2014; paper pending published: 21 February 2014; accepted: 11 March 2014; published online: 25 March 2014.

Citation: Shahjahan M, Kitahashi T and Parhar IS (2014) Central pathways integrating metabolism and reproduction in teleosts. Front. Endocrinol. 5:36. doi: 10.3389/fendo.2014.00036

This article was submitted to Experimental Endocrinology, a section of the journal Frontiers in Endocrinology.

Copyright (c) 2014 Shahjahan, Kitahashi and Parhar. This is an open-access article distributed under the terms of the Creative Commons Attribution License (CC BY). The use, distribution or reproduction in other forums is permitted, provided the original author(s) or licensor are credited and that the original publication in this journal is cited, in accordance with accepted academic practice. No use, distribution or reproduction is permitted which does not comply with these terms. 